NBER WORKING PAPER SERIES

\title{
DEFINED CONTRIBUTION PENSION PLANS: STICKY OR DISCERNING MONEY?
}

\author{
Clemens Sialm \\ Laura Starks \\ Hanjiang Zhang \\ Working Paper 19569 \\ http://www.nber.org/papers/w19569
}

\author{
NATIONAL BUREAU OF ECONOMIC RESEARCH \\ 1050 Massachusetts Avenue \\ Cambridge, MA 02138 \\ October 2013
}

The authors thank Susan Christoffersen, Zhi Da, Steve Dimmock, Nancy Eckl, Michael Halling, Jennifer Huang, Veronika Pool, Jim Poterba, Jonathan Reuter, John Simon, Irina Stefanescu, Marno Verbeek, conference participants at the 2012 SIFR Conference on Mutual Funds in Stockholm, the 2013 Asian Bureau of Finance and Economic Research Conference in Singapore, the 2013 China International Conference in Finance in Shanghai, the 2013 Conference on Professional Asset Management at the Rotterdam School of Management, and seminar participants at Georgia State University, the Hanken School of Economics, the Helsinki School of Economics at Aalto, New York University, the University of Oklahoma, the University of Texas at Austin, the University of Texas at Dallas, and the University of Virginia for helpful comments. We thank Veronika Pool and Irina Stefanescu for sharing their Form 11-K data with us. The authors also thank Tania Davila for research assistance. Clemens Sialm thanks the Stanford Institute for Economic Policy Research for financial support during his Sabbatical. Laura Starks is a trustee of mutual funds and variable annuities offered by a retirement service provider. She has also consulted for mutual fund management companies and 401(k) plan sponsors. The views expressed herein are those of the authors and do not necessarily reflect the views of the National Bureau of Economic Research.

NBER working papers are circulated for discussion and comment purposes. They have not been peerreviewed or been subject to the review by the NBER Board of Directors that accompanies official NBER publications.

(C) 2013 by Clemens Sialm, Laura Starks, and Hanjiang Zhang. All rights reserved. Short sections of text, not to exceed two paragraphs, may be quoted without explicit permission provided that full credit, including $\odot$ notice, is given to the source. 
Defined Contribution Pension Plans: Sticky or Discerning Money?

Clemens Sialm, Laura Starks, and Hanjiang Zhang

NBER Working Paper No. 19569

October 2013

JEL No. G02,G18,G23,G28,H55

\section{ABSTRACT}

Participants in defined contribution (DC) retirement plans rarely adjust their portfolio allocations, suggesting that their investment choices and consequent money flows are sticky and not discerning. Yet, the participants' inertia could be offset by the DC plan sponsors, who adjust the plan's investment options. We examine these countervailing influences on flows into U.S. mutual funds. We find that flows into funds that derive from DC assets are more volatile and exhibit more performance sensitivity than non-DC flows, primarily due to the adjustments of the investment options by the plan sponsors. Thus, DC retirement money is less sticky and more discerning.

Clemens Sialm

University of Texas at Austin McCombs School of Business

1 University Station; B6600

Austin, TX 78712

and NBER

clemens.sialm@mccombs.utexas.edu

Laura Starks

University of Texas at Austin

McCombs School of Business

1 University Station; B6600

Austin, TX 78712

laura.starks@mccombs.utexas.edu
Hanjiang Zhang

Division of Banking and Finance

Nanyang Business School

Nanyang Technological University

Nanyang Avenue, Singapore, 639798

Zhanghj@ntu.edu.sg 
Mutual fund holdings in employer sponsored defined contribution (DC) plans are an important and growing segment of today's financial markets. Assets in DC plans increased from \$1.7 trillion in 1995 to $\$ 5.1$ trillion in 2012. Further, at the end of this period, DC plans constituted $22 \%$ of total U.S. mutual fund assets and $27 \%$ of U.S. equity fund assets. ${ }^{1}$ Such holdings are expected to remain important with the increasing number of Americans moving toward retirement and with the transition of corporations and public entities towards the use of defined contribution plans rather than defined benefit (DB) plans.

Despite the prevalence of mutual fund holdings in employer-sponsored retirement accounts, little is known about the effects of DC plan sponsors (i.e., employers) and participants (i.e., employees) on mutual fund flows. Our paper analyzes the behavior of these sponsors and participants and asks the central question of whether DC pension plan investments constitute a source of sticky or discerning money for mutual funds. Conventional wisdom, based on previous studies regarding the behavior of DC plan participants, suggests that the DC plan assets in mutual funds should be sticky. ${ }^{2}$ However, the decisions regarding the composition of DC plan menus are made by DC plan sponsors, who might frequently delete funds with poor prior performance and add funds with superior prior performance. Which of these influences has a greater effect on fund flows is an empirical question that we address in this paper. Further, we consider the implications of these influences for both plan participants and the mutual fund industry.

Although investors who own mutual funds directly have the flexibility to choose among the universe of mutual funds, typically participants in employer-sponsored DC plans have limited choices. ${ }^{3}$ These choices arise through a two-stage process. In the first stage plan sponsors

\footnotetext{
${ }^{1}$ Investment Company Institute (ICI), The U.S. Retirement Market, Fourth Quarter 2012, Trends in Mutual Fund Investing, February 2013, and 2013 Investment Company Handbook, p. 114.

${ }^{2}$ See for example, Benartzi and Thaler (2001); Madrian and Shea (2001); Choi, Laibson, Madrian, and Metrick (2002); Agnew, Balduzzi, and Sunden (2003); Duflo and Saez (2003); Huberman and Jiang (2006); and Carroll et al. (2009). In contrast, evidence suggests that individual investors exhibit relatively high turnover in their traditional (directly held) brokerage accounts (e.g., Barber and Odean (2000), Grinblatt and Keloharju (2001), and Ivković and Weisbenner (2009)).

${ }^{3}$ For example, a 2011 Deloitte survey of DC plan sponsors found that the median DC plan includes 16 investment options.
} 
select the DC plan menus and adjust the investment options through time by removing or adding options. In a second stage, the employees allocate their individual DC account balances among the choices made available to them by the plan sponsors.

This two stage process contributes to different investor behavior patterns for DC plan investors versus ordinary mutual fund investors. Thus, we expect the fund flows from DC plans to behave differently than flows from non-DC sources. On the one hand, DC plan participants make periodic retirement account contributions and withdrawals, which are persistent over time. In addition, they may evaluate their present and prospective fund holdings differently from nonDC fund investors due to longer investment horizons and a different tax status. ${ }^{4}$ These aspects may explain the documented inertia by DC plan participants in the previous literature in which retirement savers are found to have a tendency to rebalance and trade infrequently and to follow default options. The documented inertia in DC plan participants' investment decisions leads to the commonly held belief that retirement money flows should have low volatility, high autocorrelation, and low sensitivity to prior fund performance.

On the other hand, the infrequent trading by individual plan participants could be offset by the plan sponsors' adjustments to the plan's menus. That is, to satisfy their fiduciary responsibilities, plan sponsors monitor the available investment options. ${ }^{5}$ They may choose to replace poorly-performing funds with investment options that exhibited superior prior performance. ${ }^{6}$ Thus, rather than being sticky, DC money could actually act as an important disciplining mechanism for fund managers, resulting in money flows that exhibit higher volatility, lower autocorrelation, and higher flow-performance sensitivity.

\footnotetext{
${ }^{4}$ The tax on income to investments in DC plans is deferred until the income is distributed. See Sialm and Starks (2012) for a discussion of tax clienteles in equity mutual funds.

${ }^{5}$ See the U.S. Department of Labor's Employee Benefits Services Administration website for information on fiduciary obligations in DC plans: http://www.dol.gov/ebsa/publications/fiduciaryresponsibility.html. Over the last decade there have been numerous lawsuits filed against plan sponsors and service providers. Most of these lawsuits allege the plans are charging excessive or hidden fees, however, the complaints have also included allegations of improper monitoring of options (http://online.wsj.com/article/SB10001424052970204777904576651133452868572.html).

${ }^{6}$ In 2011, 43\% of plan sponsors responding to a Deloitte survey of DC plans stated that they had replaced at least one fund due to poor performance within the previous year.
} 
To test these competing influences regarding the effects of DC plans on mutual fund flows, we compare the flows of DC and non-DC mutual fund investors from 1997 to 2010. We find that money flows into mutual funds by DC plan participants are more volatile and exhibit a lower serial correlation than the flows into mutual funds by other investors. Thus, DC asset flows tend to be less sticky than non-DC flows.

Furthermore, our empirical results show that DC flows react more sensitively to prior fund performance than do non-DC flows. In fact, the flow-performance sensitivity of the DC flows is particularly pronounced for funds in the lowest and highest performance quintiles. Using the piecewise linear specification of Sirri and Tufano (1998), we find that a ten percentile deterioration in prior-year performance for a bottom quintile mutual fund generates outflows of $11.9 \%$ by DC investors compared to outflows of only $3.3 \%$ by non-DC investors. On the other hand, a ten percentile improvement in prior-year performance for a top quintile mutual fund generates inflows of $17.8 \%$ by DC investors and inflows of only $4.9 \%$ by non-DC investors. Thus, contrary to the widely held conventional wisdom, we find that DC money is actually more sensitive to prior performance than non-DC money.

These results suggest that plan sponsors counteract the previously documented inertia of DC participants. To test the follow-on hypothesis that the high flow-performance sensitivity of DC funds is driven by the actions of the plan sponsor, we use data on a sample of 401(k) plans that have 11-K filings with the U.S. Securities and Exchange Commission. This data allows us to decompose flows into those resulting primarily from plan sponsor actions versus those resulting from participant actions. We find that our flow results are primarily driven by the actions of the plan sponsors and consistent with previous research, we also confirm that the plan participants themselves exhibit inertia and do not react sensitively to prior fund performance.

To investigate whether DC fund flows are more discerning than non-DC flows, we consider whether mutual fund flows from DC and non-DC investors can predict funds' long-term future return performance. Berk and Green (2004) present a model with decreasing returns to scale in fund management where fund flows rationally respond to past performance. Their model 
implies that fund flows do not predict future fund performance. For DC flows, consistent with the Berk and Green hypothesis, we find no significant predictability for future performance. On the other hand, we find that non-DC flows predict longer-term performance negatively. Overall, our results indicate that DC money is less sticky and more discerning than non-DC money.

Del Guercio and Tkac (2002), Heisler, Knittel, Neuman, and Stewart (2007), and Goyal and Wahal (2008) have provided important evidence regarding the actions of defined benefit (DB) pension plan sponsors on retirement money flows to the DB plan investment managers. This evidence does not necessarily correspond to the effects of DC plan sponsors and participants on mutual fund flows for several reasons. ${ }^{7}$ First, DB plans and DC plans exhibit very different asset allocations and the investment risks are borne by different market participants. In a DB plan the plan sponsors make the decisions regarding the portfolio allocations and the investment risks are primarily borne by the plan sponsors. On the other hand, in a DC plan the allocation decisions are made by the individual participants from options selected by the plan sponsors and the investment risks are borne by the participants. Thus, DC asset allocations are the result of a joint decision made by the actions of the plan participants and the plan sponsors. ${ }^{8}$

Second, DC plan sponsors need to consider the attraction and appropriateness of different investment options for their participants. The ultimate allocations of DB plans depend on the choices of the DB plan sponsors whereas the ultimate allocations of DC plans depend on the two-stage process described above, that is, the menu choices of the DC plan sponsors and the

\footnotetext{
${ }^{7}$ Papers on the design of DC pension plans include Lakonishok, Shleifer, and Vishny (1992); Benartzi and Thaler (2001); Madrian and Shea (2001); Choi, Laibson, Madrian, and Metrick (2002, 2006); Agnew, Balduzzi, and Sunden (2003); Duflo and Saez (2003); Brown, Liang, and Weisbenner (2007); Davis and Kim (2007); Elton, Gruber, and Blake (2006, 2007); Huberman and Jiang (2006); Rauh (2006); Goyal and Wahal (2008); Carroll et al. (2009); Cohen and Schmidt (2009); Stewart et al. (2009); Brown and Harlow (2012); Tang, Mitchell, Mottola, and Utkus (2010); Balduzzi and Reuter (2013); Christoffersen and Simutin (2013); Pool, Sialm, and Stefanescu (2013), and Rydqvist, Strebulaev, and Spizman (2013).

${ }^{8}$ Further, as pointed out by Heisler, Knittel, Neuman, and Stewart (2007), in a DB plan the sponsors may frequently rebalance their asset allocations. This rebalancing will affect investor manager flows in a DB plan. In contrast, in our setting the participants of a DC plan have control over their asset allocation. Thus, the type of rebalancing suggested by these authors would only occur if the participants made the choice, not the plan sponsor.
} 
selections of the individual plan participants. Thus, the aggregate plan allocations of DB and DC plans would be expected to differ substantially as they do. ${ }^{9}$

Third, whereas DC plans typically include mutual fund investment options, DB plans generally invest lower proportions in mutual funds. Thus, we do not have evidence on the flowperformance sensitivity of employer-sponsored retirement plan investments in mutual funds and no reason to believe they would follow the patterns documented for DB plans.

Finally, in the U.S., DC plans have become a more important retirement vehicle than DB plans. According to EBRI and the Bureau of Labor Statistics, the percentage of full-time employees at medium and large private establishments in 1993 who participated in DB and DC plans equaled 56\% and 49\%, respectively. By 2012, the percentage of DB participation of employees at medium and large private establishments declined to $28 \%$, whereas the participation in DC plans increased to $54 \%{ }^{10}$ Thus, as DC plans have gained prominence relative to DB plans, it has become important to analyze the behavior of DC plan sponsors and participants and particularly their effects on the mutual fund industry.

Having a better understanding of the impact of defined contribution plans on fund flows and their sensitivity to fund performance is important for several reasons. First, fund flows can affect the resource allocation of capital markets through their effects on asset prices. They thus influence which sectors and companies obtain financial resources. ${ }^{11}$ Second, performance-based compensation in the mutual fund industry occurs primarily through fund flows. That is, highperforming funds garner more assets and receive higher remuneration, since management fees are typically a fixed percentage of assets. It is important to understand the determinants of fund

\footnotetext{
${ }^{9}$ McFarland (2013) reports that the asset allocations for selected Fortune 1000 companies differ substantially between DB and DC plans. In 2010 the average DB asset allocation includes 48\% public equity, 34\% debt, $2 \%$ real estate, and $16 \%$ other, whereas the average DC asset allocation includes $60 \%$ public equity, $34 \%$ debt, $0 \%$ real estate, and $6 \%$ other. - A small allocation to specialized investment options (e.g., commodities, hedge funds, private equity, venture capital) is often desirable in DB plans. However, DC plan sponsors might choose to only offer such specialized choices in their retirement menus through a fund of funds such as target date funds.

${ }_{10}$ The 1993 data is available at http://www.bls.gov/ncs/ebs/sp/ebbl0024.pdf and the 2012 data is available at http://www.bls.gov/ncs/ebs/benefits/2012/ownership/private/table02a.pdf.

${ }^{11}$ See for example, Wermers (2003); Coval and Stafford (2007); and Lou (2012).
} 
flows since portfolio managers are primarily incentivized through fund flows. ${ }^{12}$ Finally, fund flows exert externalities on the remaining fund investors. For example, fund flows can require fund managers to adjust their portfolios, incur trading and tax costs, and change their investment strategies. $^{13}$

The remainder of this paper is organized as follows. Section I describes the data sources and gives summary statistics. Section II compares the standard deviations and the autocorrelations of fund flows in DC and non-DC environments. Section III analyzes the flowperformance relation for DC and non-DC fund assets. Section IV contrasts the impact of plan sponsors and plan participants on the flow-performance relation of DC assets. Section V studies the performance predictability of DC and non-DC fund flows and Section VI concludes.

\section{Data}

\section{A. Data Sources}

We employ several different databases for our analysis. The first set of data is obtained from annual surveys of mutual fund management companies conducted by Pensions \& Investments over the $1997-2010$ time period. ${ }^{14}$ In these surveys the companies are asked to report the dollar amount of the mutual fund assets held in Defined Contribution (DC) retirement accounts (as of December $31^{\text {st }}$ of the year prior to the survey date) for the mutual funds most used by DC plans. ${ }^{15}$ Mutual fund families are asked in the survey to report the DC plan assets for

\footnotetext{
${ }^{12}$ See for example, Brown, Harlow and Starks (1996); Chevalier and Ellison (1997); Sirri and Tufano (1998); Del Guercio and Tkac (2002, 2008); Berk and Green (2004); Huang, Wei, and Yan (2007, 2012); Ivkovich and Weisbenner (2009); and Del Guercio and Reuter (2013).

${ }^{13}$ See for example, Barclay, Pearson, and Weisbach (1998); Edelen (1999); Khorana and Servaes (1999); Dickson, Shoven, and Sialm (2000); Bergstresser and Poterba (2002); Alexander, Cici and Gibson (2007); Christoffersen, Geczy, Musto, and Reed (2006); Coval and Stafford, (2007); Chen, Goldstein and Jiang (2010); and Sialm and Starks (2012).

${ }^{14}$ We thank David Klein from Pensions \& Investments for providing us with the survey data. Additional information about the survey can be obtained from the website at http://www.pionline.com. Earlier surveys from the same data source have been used previously by Christoffersen, Geczy, Musto and Reed (2006) and Sialm and Starks (2012). In a contemporaneous paper Christoffersen and Simutin (2013) investigate the risk taking incentives of mutual funds with different investor clienteles.

${ }^{15}$ The sample includes 401(k), 403(b), 457, profit sharing, and other defined contribution plan assets. This specifically excludes other tax qualified investment vehicles that could be held in mutual funds such as Individual
} 
the twelve funds with the largest DC assets in each of several broad investment categories (Domestic Equity Funds, Domestic Fixed Income Funds, International Equity Funds, Balanced Funds, Money Market Funds). We focus on the category of domestic equity funds because they are the most used mutual funds in DC plans over our sample period and because we can abstract from changes in asset classes across the plans. ${ }^{16}$

Our second set of data, which is derived from the CRSP Survivorship Bias Free Mutual Fund database, consists of mutual fund characteristics such as fund returns, total assets under management, fees, and investment objectives. To avoid the incubation bias described by Evans (2010), we exclude funds which in the previous month managed less than \$5 million, funds with missing fund names in the CRSP database, and funds where the year for the observation is in the same year or in an earlier year than the reported fund starting year. For funds with multiple share classes, we combine the classes into one observation per fund and compute the fund-level variables by aggregating across the different share classes. We merge the CRSP data with the survey data using the funds' ticker symbols and names. We also merge the CRSP database with the Thomson Financial CDA/Spectrum holdings database and the CRSP stock price database using the MFLINKS file based on Wermers (2000) and available through the Wharton Research Data Services (WRDS).

In order to understand the generalizability of our analysis, we compare the domestic equity funds listed in the Pensions \& Investments dataset to those included in the CRSP database. We find that the Pensions \& Investments dataset has wide coverage - the fund families in our sample control over $77 \%$ of the total value of equity funds included in CRSP. In addition, although we do not have the level of DC assets for all funds in families that have many mutual funds, the levels of assets that we do have indicate that the excluded funds tend to have relatively

Retirement Accounts (IRAs), Keoghs and SARSEPs. It also does not include other retirement assets under administration by the fund family such as sponsoring company stock.

16 Specifically, we eliminate balanced, bond, international, and money market funds, as well as funds that, on average, hold less than $80 \%$ of common stock. Index funds are included. However, our results are not affected qualitatively if we exclude index funds. Target date funds are not included in this classification because they are typically funds of funds and tend to hold bond funds as well as equity funds. 
low DC assets. In particular, the funds in our database (with non-censored DC assets) account for $85 \%$ of the total equity assets of the surveyed fund families.

Our final data set derives from plan sponsors’ required annual Form 11-K filings with the Securities and Exchange Commission (SEC). ${ }^{17}$ These filings are only required when an employer offers company stock as part of their DC plan. Included in the information on Form 11-K are the values of assets in each of the plan's investment options along with the name of the mutual fund or other plan provider. This data set allows us to decompose the fund flows from the plan into flows driven primarily by the actions of plan sponsors and flows driven primarily by plan participants.

\section{B. Flow Definitions}

Using the Pensions \& Investments data we divide the flows into DC flows and non-DC flows as follows:

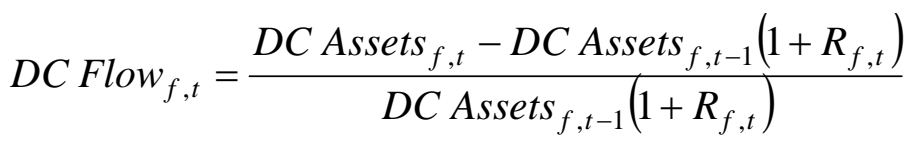

$$
\begin{aligned}
& \operatorname{NonDC~Flow~}_{f, t}=\frac{\text { NonDC Assets }_{f, t}-\text { NonDC Assets }_{f, t-1}\left(1+R_{f, t}\right)}{\text { NonDC Assets }_{f, t-1}\left(1+R_{f, t}\right)}
\end{aligned}
$$

where DC Flow $_{f, t}$ denotes the defined contribution flows to fund $f$ in year $t$ based on the difference between the end of year DC assets in the fund less the product of the beginning of year DC assets and one plus the fund's return in that year. The denominator ensures that the fund flows never fall below $-100 \%$. The NonDC Flow $f, t$ is defined analogously where NonDC Assets $s_{f, t}$ are fund $f$ 's total assets at time $t$ less the fund's DC assets at time $t$ adjusted for the fund returns.

\footnotetext{
${ }^{17}$ We thank Veronika Pool and Irina Stefanescu for providing us with the data. Additional information on the data can be obtained from Pool, Sialm, and Stefanescu (2013). Their paper analyzes favoritism by mutual fund families toward their own affiliated funds.
} 
The 11-K data give us the assets of plan $p$ invested in mutual fund $f$ at time $t$ (Assets $p, f, t)$. We aggregate across all plans invested in fund $f$ at times $t$ and $t-1$. That is, to obtain the Plan Flow of fund $f$ at time $t$ using the 11-K data, we sum the estimated dollar flows across all plans that offer the fund and divide this aggregate flow by the aggregate initial plan value adjusted for the fund return. We only compute the plan flow for a fund if at least one 401(k) plan in the 11-K data offers that specific mutual fund in the prior year.

$$
\operatorname{PlanFlow~}_{f, t}=\frac{\sum_{p} \text { Assets }_{p, f, t}-\sum_{p} \text { Assets }_{p, f, t-1}\left(1+R_{f, t}\right)}{\sum_{p} \text { Assets }_{p, f, t-1}\left(1+R_{f, t}\right)}
$$

Although we cannot observe the individual allocation decisions of plan participants and sponsors, we do observe whether a new investment option is included in a plan or whether an old option is excluded by comparing the asset allocations from one year to the next. Since the plan sponsor determines the changes in the menu, we term the flows due to fund additions and deletions as Plan Sponsor Flow:

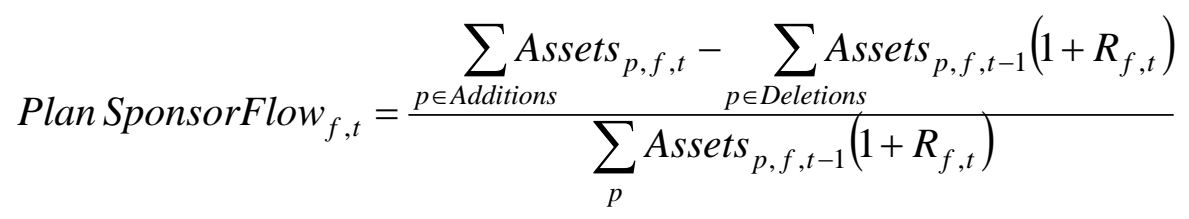

The residual flows are termed Plan Participant Flows, because plan participants can generally allocate their retirement funds freely between the various investment options provided in the plan's menu: ${ }^{18}$

\footnotetext{
${ }^{18}$ Plan sponsors might also influence the residual Plan Participant Flows due to incremental changes in the plan design. Examples of sponsor decisions that could also influence Plan Participant Flows include closures of mutual funds to new investments while grandfathering current fund holdings, selection of specific funds as default investment options, and additions of new funds that compete with incumbent funds. On the other hand, it is unlikely that Plan Sponsor Flows would capture direct allocation decisions solely made by plan participants. This would only happen if all plan participants would coordinate their allocation decisions and completely avoid investing in a fund that is an available menu choice. Thus, our measure of Plan Sponsor Flow likely underestimates the influence of sponsors and overestimates the influence of participants.
} 


$$
\text { Plan Participant } \text { Flow }_{f, t}=\text { Plan Flow }_{f, t}-\text { Plan Sponsor Flow }_{f, t}
$$

\section{Summary Statistics}

Our primary sample of merged data from the CRSP and Pensions \& Investments databases covers 1,078 distinct equity funds and 5,808 fund-year observations over the period between 1996 and 2009. Panel A of Table I shows the summary statistics. The equal-weighted mean of the proportion of assets in the mutual funds held in DC plans (DC Ratio) is 25.4\%, with the first quartile being $8.5 \%$ ranging up to $35.5 \%$ for the third quartile. However, some large actively managed funds have very high DC ratios. For example, in 2010, Fidelity’s Contrafund had a DC ratio of 65.9\%, Vanguard's Primecap Fund had a DC ratio of 53.4\%, and American Fund's Growth Fund of America had a DC ratio of 42.5\%. Table I also shows that the funds in the sample have average assets under management of around $\$ 3.9$ billion, come from a fund family with an average of $\$ 57.2$ billion in assets under management, are on average 16 years old, charge an average expense ratio of $1.16 \%$, exhibit an average turnover rate of $78 \%$, and have an average annual return of $6.8 \%$.

To reduce the impact of outliers, we winsorize the extreme fund flows at the $2.5 \%$ level. Table I shows that the annual growth in DC assets for the average fund in our sample has been much larger than the annual growth in the Non-DC assets at $32.0 \%$ compared to $6.7 \%$. Part of this difference is due to the fact that DC assets start on average from a smaller base.

The data from the annual Form 11-K filings indicate that this sample's 401(k) plans include on average 9.8 equity mutual funds over the sample period from 1999 to 2009. The average number of equity mutual fund options has increased from 5.9 in 1999 to 12.2 in 2009. The 11-K filings indicate that plan sponsors adjust their investment menus frequently. On average, plans delete 1.2 domestic equity fund options and include 1.9 new domestic equity fund options every year. Table I shows that plan flows into the mutual funds on the menu average around $22.3 \%$ with a median of $3.6 \%$, indicating that a substantial proportion of flows are concentrated on a relatively small number of funds. Dividing these flows between sponsors and 
participants shows that sponsor decisions result in an average annual inflow of $9.7 \%$ and plan participants' actions lead to an average annual flow of $12.6 \%$. The standard deviation of plan sponsor flows is around three times higher than the standard deviation of plan participant flows, indicating that most fund flows in 401(k) plans are caused by the addition and deletion decisions of plan sponsors.

Panel B of Table I summarizes the correlations between the key variables. While the DC ratio for a fund is positively correlated with fund and family size, it is negatively correlated with fund age, expense ratio, and fund turnover. Thus, DC plans tend to focus on large but relatively younger mutual funds with lower expense ratios and lower portfolio turnovers. Finally, the various flow measures are all positively correlated, suggesting that the flows of different market participants are following similar signals.

\section{Standard Deviation and Autocorrelation of Fund Flows}

The documented inertia of DC plan participants leads to the commonly held belief that DC flows into mutual funds should have lower volatility than other investor flows. Moreover, given the stability of contributions and withdrawals into DC plan retirement accounts over time, one would also expect a higher autocorrelation of flows from DC plans than that from non-DC plans. Table I, however, provides preliminary evidence against these hypotheses in that DC flows tend to be substantially more volatile than non-DC flows. This relation is at first glance surprising given the relative stability in DC contributions and withdrawals over time. However, since plan sponsors and their participants can reallocate their DC assets across different mutual funds their actions could create more volatile flows for funds with high DC assets. The tests in this section are designed to evaluate these alternative hypotheses in more detail.

To test whether DC money is more stable than non-DC money in mutual funds, we examine the relation between the standard deviation (or the autocorrelation) of the growth rate of new money and fund characteristics. Specifically, for each fund in our sample, we compute the standard deviation and the autocorrelation of the annual flow over the time period the fund 
appears in our sample. ${ }^{19}$ In the regressions we pool the DC and non-DC flows together and regress the moments against an indicator variable for DC investor flows along with control variables that are evaluated at the beginning of the respective time periods. We report the results in Table II. In the first and fourth columns of the table, the indicator variable is the sole independent variable. In the second and fifth columns we add control variables for fund characteristics, such as the logarithm of fund size, the logarithm of family size, the logarithm of fund age, the expense ratio, and the portfolio turnover. The continuous control variables are demeaned so that we can interpret the constant as the fitted moments for non-DC funds evaluated at the means of the control variables. Finally, in the third and sixth columns we also include interaction effects between the DC indicator variable and the demeaned control variables.

Regardless of the specification, we find significant differences in the behavior of the DC flows as compared to the other flows. First, the standard deviation of DC flows exceeds the corresponding moment of non-DC flows. For example, the standard deviation of annual DC flows exceeds the standard deviation of non-DC flows by between $21.2 \%$ and $52.2 \%$ per year depending on whether we adjust for other fund characteristics. After adjusting for fund characteristics, the difference in standard deviations is reduced, but still highly significant. The reason for the reduction is primarily because the level of DC assets in a fund tends to be smaller than the level of non-DC assets. Second, we find that the autocorrelation of DC flows is significantly lower than that for non-DC flows in all specifications. These results support the hypothesis that DC flows are not stickier than non-DC flows. In fact, counter to conventional wisdom, the DC flows are actually significantly more volatile and less autocorrelated than nonDC flows. These results support the hypothesis that DC plans have significant effects on the mutual funds in which their assets are invested. The extent of these effects is explored in more detail in the following section.

\footnotetext{
${ }^{19}$ For this part of the analysis, in order to compute these moments we require funds to have at least five years of available flow data.
} 


\section{Flow-Performance Relation for DC and Non-DC Assets}

We next test hypotheses regarding the flow-performance sensitivity of DC versus nonDC assets by examining the percentage flows by DC and non-DC assets separately. We have hypothesized that a difference in the flow-performance sensitivity in the two environments could occur because the actions of plan sponsors and participants could be different from that of direct mutual fund investors. Two alternative hypotheses exist regarding these differences. First, a lower flow-performance sensitivity for DC assets would be expected if plan sponsors and their participants exhibit inertia by not changing their DC account portfolio allocations as frequently as do non-DC investors in directly held mutual fund accounts. The second, contrasting hypothesis considers the possibility that DC plan sponsors or participants are actively adjusting their plan choices based on prior fund performance. In this case, DC assets would exhibit more flow-performance sensitivity. ${ }^{20}$ Moreover, the heightened sensitivity would be expected under both low and high performance if it is due to the plan sponsor replacement process. That is, when plan sponsors adjust their investment option menus by moving participants' assets from a poorly performing fund to a replacement fund, this action would induce flow-performance sensitivity in the lower performance range. Correspondingly, since the plan sponsors' replacement process typically restricts the replacement fund to a set of better performing funds in the same investment objective group as the previous fund, this process would also induce flow-performance sensitivity in the higher performance range.

\section{A. Estimation Method}

In this section we compare the flow-performance relation for DC and non-DC assets. For each fund in our sample we employ the Pensions \& Investments data to separate the DC and non-

\footnotetext{
${ }^{20}$ Plan sponsors and participants may behave differently in such situations. We expect the observed flowperformance sensitivity to reflect the dominant forces between these two parties. We compare the behavior of plan sponsors and participants in Section IV.
} 
DC assets and compute the annual percentage flows (growth rates) of DC and non-DC assets according to equations (1) and (2).

To capture the flow-performance sensitivity, we relate these annual flows to the relative fund performance rank (Rank) over the prior year while controlling for other lagged fund characteristics, such as the logarithms of the total DC and non-DC assets (DC Size and NonDC Size), the logarithm of family TNA (Fam Size), the logarithm of the time period since fund initiation (Age), the lagged expense ratio (Exp), the lagged annual turnover of the fund (Turn), the monthly return volatility over the prior year ( $\mathrm{Vol})$, the average contemporaneous flow of funds in the same style category (SFlow), and year fixed effects $(\beta)$ :

$$
\begin{aligned}
\text { Flow }_{f, t} & =f\left(\operatorname{Rank}_{f, t-1}\right)+\beta_{1} \text { DC Size }_{f, t-1}+\beta_{2} \text { NonDC Size }_{f, t-1}+\beta_{3} \text { Fam Size }_{f, t-1} \\
& +\beta_{4} \text { Age }_{f, t-1}+\beta_{5} \operatorname{Exp}_{f, t-1}+\beta_{6} \text { Turn }_{f, t-1}+\beta_{7} \text { Vol }_{f, t-1}+\beta_{8} \text { SFlow }_{f, t}+\beta_{t}+\varepsilon_{f, t}
\end{aligned}
$$

We define the fund performance measure $\operatorname{Rank}_{f, t}$ as the percentile performance rank a particular fund $f$ obtains across all equity funds in the sample during a specific performance evaluation period. Funds in the worst performance percentile obtain a rank of 0.01 and funds in the best performance percentile obtain a rank of $1.00 .^{21}$

To capture non-linearities in the flow-performance relation we use two different functional forms for $f\left(\operatorname{Rank}_{f, t}\right)$. The first non-parametric functional form simply estimates separate effects for each percentile:

$$
f_{1}\left(\operatorname{Rank}_{f, t}\right)=\sum_{j=1}^{100} \gamma_{j} I\left(100 \times \operatorname{Rank}_{f, t}=j\right)
$$

\footnotetext{
${ }^{21}$ We also present robustness tests in which the performance rank is computed within objective-code categories, within holdings-based style categories, and using the Carhart (1997) four-factor adjusted performance measure over the prior year.
} 
where $I(100 \times$ Rank $=j)$ is an indicator variable that equals one if the performance rank of a specific fund falls in the $j^{\text {th }}$ percentile and zero otherwise. The coefficient $\gamma_{j}$ captures the average flow of funds in the $j^{\text {th }}$ percentile if all the other covariates of equation (4) are equal to zero. In this specification we estimate 100 different performance-sensitivity coefficients $\gamma$.

A second functional form follows Sirri and Tufano (1998) and estimates a piecewise linear specification:

$$
f_{2}\left(\operatorname{Rank}_{f, t}\right)=\gamma_{L} \operatorname{Low}_{f, t}+\gamma_{M} \operatorname{Mid}_{f, t}+\gamma_{H} \operatorname{High}_{f, t},
$$

where $\operatorname{Low}_{f, t}=\min \left(\operatorname{Rank}_{f, t} 0.2\right) ; \operatorname{Mid}_{f, t}=\min \left(\operatorname{Rank}_{f, t}-\operatorname{Low}_{f, t} 0.6\right)$; and $\operatorname{High}_{f, t}=\left(\operatorname{Rank}_{f, t}-\right.$ $\left.\operatorname{Low}_{f, t}-\operatorname{Mid}_{f, t}\right)$. The performance coefficients $\gamma_{L}, \gamma_{M}$, and $\gamma_{H}$ capture the marginal flowperformance sensitivities in the bottom quintile, in the three middle quintiles, and in the top

quintile, respectively. For example, a fund in the $15^{\text {th }}$ percentile would experience flows of $0.15 \times \gamma_{L}$ if all the other covariates were equal to zero. On the other hand, a fund in the $85^{\text {th }}$ percentile would experience flows of $0.2 \times \gamma_{L}+0.6 \times \gamma_{M}+0.05 \times \gamma_{H}$ if all the other covariates were zero. This specification estimates a continuous piecewise linear function.

\section{B. Percentile Flows}

Figure 1 depicts the flow-performance relation for DC and non-DC assets using the nonparametric specification with percentile ranks. The dots show the average flows for the 100 performance groups, where the remaining covariates are evaluated at their sample means. The diamonds correspond to DC flows and the circles correspond to non-DC flows. The solid curves show the least-squares cubic relation. Since the funds in our sample are held in both DC and nonDC environments, for each fund we calculate two different asset growth rates corresponding to DC assets and non-DC assets. Thus, the fund composition of the various performance rank percentiles between DC and non-DC portfolios are identical and the flow differences between DC and non-DC assets cannot be explained by differences in fund characteristics. 
We observe that DC assets on average experience larger fund flows than non-DC assets due to the significant growth of tax-qualified retirement accounts over our sample period. Funds with performance ranks in the middle $10 \%$ (i.e., funds with performance ranks between the $46^{\text {th }}$ and the $55^{\text {th }}$ percentile) experience inflows of $23.7 \%$ for DC assets and $2.1 \%$ for non-DC assets.

Whereas the flow-performance relation is close to linear for non-DC assets, the relation is clearly non-linear for DC assets. Further, the flow-performance relation is particularly steep for DC assets corresponding to funds in the top and bottom performance groups. For example, funds in the bottom decile of performance experience an average outflow of $8.3 \%$ of their DC assets and funds in the top decile experience an average inflow of $53.6 \%$ of their DC assets. On the other hand, funds in the bottom decile experience an average outflow of $11.8 \%$ of their non-DC assets and funds in the top decile experience an average inflow of $17.9 \%$ of their non-DC assets. Although bottom decile funds experience similar DC and non-DC flows, the low growth of DC assets of poorly performing funds is meaningful given the substantial growth of DC assets over our sample period. $^{22}$

\section{Piecewise Linear Specification}

The non-parametric flow-performance relation from Figure 1 justifies the piecewise linear specification suggested by Sirri and Tufano (1998), who estimate different flowperformance sensitivities for the top and bottom performance quintiles. The results of these alternative panel regressions are summarized in Table III. The first three columns are based on the fund performance over the prior year, whereas the last three columns are based on fund performance over the prior five years. For each horizon, we report the coefficient estimates for DC and non-DC percentage flows and the coefficient estimates for a regression in which the dependent variables equal the difference between the DC and the non-DC percentage flows. The

\footnotetext{
${ }^{22}$ Unreported tests using the first three polynomials of fund performance ranks indicate that only the cubic term on the demeaned fund performance rank is statistically significant for DC flows, whereas only the linear term on the performance rank is statistically significant for non-DC flows. These results are available in Table A-I in the Appendix.
} 
standard errors of the coefficients are reported in parentheses and adjust for clustering at the fund level. The regressions include time-fixed effects.

Consistent with Figure 1, Table III indicates an economically and statistically significant flow-performance relation for the extreme performance quintiles using the DC flows for both the 1-year and 5-year performance periods. A ten-percentile increase in the performance rank over the prior year increases the DC flows by $11.9 \%$ for the bottom quintile, by $2.4 \%$ for the middle three quintiles, and by $17.8 \%$ for the top quintile. On the other hand, the flow-performance relation is more linear for the non-DC flows. For example, a ten-percentile increase in the performance rank over the prior year increases the non-DC flows by $3.3 \%$ for the bottom quintile, by $2.8 \%$ for the middle three quintiles, and by $4.9 \%$ for the top quintile. The third column indicates that the differences in flow-performance sensitivities are significant for the top and bottom performance quintiles. We illustrate the results of this linear piecewise regression in Figure 2, which depicts the flow-performance relation for DC and non-DC flows evaluated at the means of the remaining covariates. ${ }^{23}$

Consistent with Sirri and Tufano (1998), we find that the sensitivity to the one-year performance is generally stronger than the sensitivity to longer-term performance measures. This difference in sensitivity is less pronounced for DC flows than for non-DC flows. Although the DC flows are the result of a joint decision by plan sponsors and participants and as explained earlier the role of plan sponsors in DC plans is fundamentally different from that of DB plan sponsors, it can still be instructive to compare our results to those of studies on DB plan sponsors. In particular, Del Guercio and Tkac (2002) and Heisler, Knittel, Neumann, and Stewart (2007) document that DB pension clients do not flock disproportionately to recent winners, which varies from our results for DC plans. However, our results are consistent with those of

\footnotetext{
${ }^{23}$ The results are not affected qualitatively if we use the Fama-MacBeth (1973) estimation method, as summarized in Table A-II in the Appendix. Furthermore, as shown in Table A-III in the Appendix, the results are similar if the piecewise linear segments are estimated based on the funds with performance ranks in the highest or lowest $10 \%$ or $30 \%$ of the sample.
} 
Goyal and Wahal (2008), who find that DB plan sponsors hire investment managers after they earn large positive excess returns.

Important remaining explanatory variables for fund flows in Table III are the sizes of the DC and non-DC assets invested in the fund and the size of the fund family. The fund's DC asset size has a negative effect on DC flows for both the one- and the five-year horizon and the fund's non-DC asset size has a negative effect on the non-DC flows. These negative effects would be expected because the growth rates of fund flows tend to decline with the size of the assets under management. The positive effects of family size capture positive spillovers between non-DC and DC clienteles, which is also reflected in the positive coefficient on non-DC size with DC flows. Thus, funds from larger fund families tend to attract both DC and non-DC assets with no significant difference between the two.

The flow-performance relation for DC assets in mutual funds differs substantially from the relation reported in the literature for mutual funds in general. (See, for example, Chevalier and Ellison (1997), Sirri and Tufano (1998), Huang, Wei, and Yan (2007), and Kim (2011), among others.) These studies typically find a convex flow-performance relation for the total mutual fund assets. Our results provide a contrast as we find that as a group, DC savers and their sponsors appear to be monitoring their mutual funds more closely than traditional mutual fund investors, resulting in a more sensitive flow-performance relation for extreme performers.

\section{E. Alternative Performance Benchmarks}

Since performance can be measured in many different ways, in this section we consider the flow-performance relation for alternative performance measures. The results are summarized in Table IV. The first set of columns ranks our sample of funds within the three objective codes given by the Thomson Financial fund holdings database for domestic equity mutual funds (Aggressive Growth, Growth, Growth and Income). The second set of columns uses holdingsbased style measures to rank the performance of funds. Following Daniel, Grinblatt, Titman, and Wermers (1997) and Wermers (2003), we group each stock listed in CRSP into respective 
quintiles according to its market value (using NYSE cutoff levels) and its industry-adjusted book-to-market ratio. Using the quintile information of stocks held by a mutual fund, we compute the value-weighted size and book-to-market scores for each fund in each period. Mutual funds are subsequently divided into terciles according to their average size score and their average book-to-market score. Based on the size and book-to-market terciles, we form nine style groups. Finally, each year we rank the equity funds within each of the nine size and book-tomarket groups according to their raw performance. The third set of columns in Table IV ranks mutual funds according to their Fama-French-Carhart alphas over the prior year using weekly returns, which reflect the funds' performance after adjustment by a market factor, a size factor, a book-to-market factor, and a momentum factor. For all models we rank the performance of the

funds over the prior 12 months. Furthermore, the specifications control for the standard deviations of the objective-adjusted, the style-adjusted, and the four-factor adjusted returns during the prior year. These volatilities correspond to the tracking errors relative to the respective benchmark returns. In all three alternative specifications we find that the sensitivity of flows to prior performance is stronger for DC assets than for non-DC assets confirming our previous results. Thus, our results are not driven by style or objective effects.

\section{F. Different Subperiods}

The structure of DC pension plans has evolved substantially over our sample period. Possible drivers of this evolution include regulatory changes, participant lawsuits, and pressure from employees and the public. For example, some of the structural changes include the broadening of the available investment choices, the movement toward a more open architecture in which the plan menus include investment options from different providers, the adoption of 
automatic enrollment, which directs new funds into the default fund specified by the plan, and the movement away from fixed income default funds to target date default funds. ${ }^{24}$

Beyond the changes in plan structures, the behavior of fund investors could also vary across different market environments. For example, Kim (2011) does not find convexity in the flow-performance relation during the 2000s when markets are volatile and there is less dispersion in performance across funds.

To investigate whether plan structure and market environment changes have affected the flow-performance relation over our sample period, we divide our sample into two equal subperiods (1996-2002 and 2003-2009). Table V reports the results of the piecewise linear specification over the two subperiods. For the non-DC assets we find a significant convex flowperformance relation between 1996 and 2002, which disappears between 2003 and 2009. On the other hand, for the DC assets we find a strong flow-performance sensitivity for the bottom and the top performance quintiles over the later period (between 2003 and 2009). Interestingly, the sensitivity of flows to bottom quintile performance for DC assets is relatively weak over the earlier period (1996-2002) and strengthens significantly during the subsequent period (20032009). Thus, DC plans become more sensitive to poor performance over the recent time period, which may be due to participant lawsuits, pressure from employees and the public, and regulatory changes.

\section{G. Interactions with Asset Size and Age}

The flow-performance sensitivity might differ depending on the size and the age of the mutual funds. Although we control in the previous specifications for the logarithms of DC and non-DC asset sizes and for the logarithm of the age of the funds, these specifications do not allow the flow-performance relation to differ by asset size or fund age. Thus, in this section we

\footnotetext{
${ }^{24}$ See Campbell et al. (2011) for an analysis of recent changes in DC accounts. The Pension Protection Act (PPA) of 2006 changed the regulatory environment of DC plans and induces employers to incorporate automatic enrollment, automatic contribution escalation, and a diversified default asset allocation.
} 
consider these potential factors since the DC and the non-DC asset sizes are related to the distribution of flows. In Table VI we use the one-year performance specifications from Table III and add controls for the interactions between the fund performance variables and the demeaned fund characteristics of size and age. The results show that none of the interaction coefficients are significant at a 5\% significance level. Furthermore, the estimated coefficients on the three piecewise linear performance segments remain very similar to the results reported in Table III. $^{25,26}$

\section{H. Sample Selection}

One potential concern regarding our analysis is whether selection bias could be affecting our results. That is, we typically observe only the amount of DC assets for a fund family's 12 domestic equity funds that have the largest amount of DC assets. Since some mutual fund families have more than 12 domestic equity funds, we might not observe the DC assets for smaller funds within that family or for funds with relatively small proportions of DC assets. ${ }^{27}$ This sample selection could be problematic because of our inability to compute the DC and the non-DC flows for funds that enter and exit our sample and thus, these funds would be missing from our analysis. Furthermore, this sample selection issue could be more problematic for small funds, since large funds are more likely to consistently remain in the sample.

To analyze the relevance of this sample selection issue we examine the likelihood of exit and entrance of funds according to their characteristics, including performance. Thus, we consider funds that listed DC assets in the prior period and have missing DC assets in the current

\footnotetext{
${ }^{25}$ For the interaction effects we use the demeaned logarithm of DC size, the demeaned logarithm of non-DC size, and the demeaned logarithm of age, so that the coefficients on the piecewise linear performance ranks can be interpreted as the coefficients of funds at the means of the logarithms of the corresponding variables.

${ }^{26}$ For additional robustness tests, we replace the percentage DC and non-DC flows with the percentiles of DC and non-DC flows. Consistent with our base case specification in Table III, we find that the percentile DC flows are more sensitive to top and bottom quintile performance than the middle three performance quintiles. Furthermore, the relation is close to linear using the percentile of non-DC flows. The results are available in Table A-IV in the Appendix.

${ }^{27}$ It should be noted, however, that some fund families provide the information on more than 12 funds.
} 
period (exit funds) and funds that had missing DC assets in the prior period and have available DC assets in the current period (entry funds). ${ }^{28}$

Table VII reports the coefficient estimates of a multinomial logit regression for fund entry and exit decisions. The base group corresponds to funds that have non-missing DC assets for two consecutive time periods. We find that funds with poor prior performance have a higher probability of exiting the sample and funds with superior prior performance have a higher probability of entering the sample.

These results are consistent with our earlier results regarding the flow-performance sensitivity of DC assets. The results indicate that DC assets are more likely to flee poorly performing funds (and thus, become missing from the data set), if the fund experiences poor prior performance. Similarly, DC assets in a fund are more likely to increase and cause the fund to enter the data set if the fund experiences superior prior performance. Moreover, these selection effects likely attenuate the flow-performance relation for DC assets in our base case specifications. Taking into account these selection effects would likely further increase the sensitivity of DC flows to performance.

\section{Plan Sponsor versus Plan Participant Decisions}

Our results in the previous section show that the performance-sensitivity of DC asset flows is higher than that of non-DC asset flows, which suggests that either DC plan sponsors or their participants are actively making decisions on plan holdings related to the funds' performance. To determine which of these parties is more important, we employ data from the SEC Form 11-K which allows us to separate plan sponsor actions from those of their participants. Our identification in this decomposition considers that when plan sponsors add an investment option to plan menus, the option and its assets will appear on the subsequent Form 11-K filings. On the other hand, when plan sponsors terminate an investment option, the assets in

\footnotetext{
${ }^{28}$ Since we are interested in the entries and exits of individual funds in the Pensions \& Investments list, we do not include the entries and exits of mutual funds that are determined by the entries and exits of whole families.
} 
that option usually are mapped to a replacement option. Thus, the changes by plan sponsors will be reflected in the annual flows associated with the appearance or disappearance of an investment option on plan menus and such flows can be attributed primarily to decisions by the plan sponsors. The annual flows at other times can be attributed primarily to participants.

The differences in flow-performance sensitivity of the flows attributed to plan sponsors versus plan participants are striking as is illustrated in Figure 3 in which we evaluate the covariates of equation (6) at their sample means. Figure 3 depicts the plan flows and the estimated participant flows for percentile portfolios formed according to the prior-year fund return, where plan flow is computed based on equation (3) and captures the total growth of fund assets held in 401(k) plans. The participant flows are based on equation (5) and capture the fund flows that are not driven by addition and deletion decisions by plan sponsors. The distance between plan flows and the participant flows capture the sponsor flows.

Figure 3 illustrates that most of the flow-performance sensitivity is driven by addition and deletion decisions of plan sponsors. On the other hand, the participant flows are only weakly related to the prior fund performance.

Using the piecewise linear specification based on fund performance over the prior year, we assess the flow-performance sensitivities of plan sponsors and participants separately while controlling for other fund characteristics. The results of these regressions are summarized in Table VIII. In the first three columns we use the Pensions and Investments sample of funds used in our earlier tests and report the coefficient estimates for total percentage flows, flows ascribed to plan sponsors and flows ascribed to plan participants, respectively. The second set of regressions in columns 4-6 are based on all funds included in the Form 11-K filings with the requisite information on CRSP. The regressions include time-fixed effects. The standard errors of the coefficients, which have been adjusted for clustering at the fund level, are reported in parentheses.

Consistent with our earlier results in Table III for the DC assets, when examining the total plan flows in the first column, we find a stronger flow-performance relation for the extreme 
performance quintiles, with larger coefficients for the low and high returns. We find this same general relation also holds when we focus on only the sponsors' actions in column 2. In contrast, when we examine the flows generated by participants, we find a much weaker flow-performance relation. The participants neither invest more in high performers nor significantly pull out of low performers. Thus, comparing the results in columns 2 and 3 shows that the flow-performance sensitivity we have documented in the earlier tests is primarily driven by the sponsors' actions in adding and deleting funds on the plan menu rather than the participants' actions in making their menu choices.

We also find that plan size, fund size and the fund's expense ratio are important for both plan sponsor and participant flows. In particular, the plan sponsors and participants invest more into funds with lower expense ratios.

Because our Pension \& Investments sample is weighted toward larger funds and larger fund families, in the last three columns we report the results of analyses that include all funds in the 11-K sample. Although we find more muted results, we continue to find significant flowperformance sensitivity among these funds and that the flow-performance sensitivity results are driven by plan sponsors, rather than plan participants. ${ }^{29}$

Overall, our results using the data on plan flows provide support to the hypothesis that the flow-performance sensitivity we find for DC assets in the larger data set is being driven by purposeful actions of plan sponsors.

\footnotetext{
${ }^{29}$ The flow results of the expanded 11-K sample are likely noisier since they only cover a subsample of DC plans because Form 11-K only needs to be filed for companies that have employer stock as an investment option in their 401(k) plans. Furthermore, the 11-K sample only covers 401(k) accounts and does not include other DC types (e.g., 403(b), 457, profit sharing, and other defined contribution plan assets), which are included in the Pensions \& Investments sample. On the other hand, the $11-\mathrm{K}$ sample covers a larger number of funds than the Pensions \& Investments sample, since not all fund families participate in the Pensions \& Investments survey and since the survey typically lists each family's twelve funds in an investment category with the largest DC assets. For our purposes to separate and compare between DC and non-DC fund flows, it is more appropriate to use the complete DC assets in the Pensions \& Investments data, but we include the total funds in the 11-K sample for robustness.
} 


\section{Performance Predictability}

The previous tests have shown that DC flows tend to leave poorly performing funds and move into higher performing funds, suggesting that they chase performance. However, this result does not necessarily imply that DC money is smart, that is, that DC money can predict future fund abnormal performance. In fact, Berk and Green (2004) derive in a rational model that flows should not predict future abnormal performance. They assume that skilled managers will attract larger flows and that the resulting increase in fund size will subsequently deteriorate the average investment ability of these managers due to decreasing returns to scale. The empirical evidence suggests that flows are smart in the short term (Gruber (1996) and Zheng (1999)) but dumb at longer horizons (Frazzini and Lamont (2008)). That is, flows show positive predictability in the short term, but negative predictability in the long term.

The relative sophistication of the plan sponsors and their use of consultants suggests that DC fund flows should be more discerning than non-DC flows. Thus, we test whether mutual fund flows from DC or non-DC investors can predict funds’ long-term future performance. Since we only have annual measures of DC and non-DC flows, we run our performance predictability regressions at an annual frequency.

$$
\begin{aligned}
& \operatorname{Perf}_{f, t}=\beta_{1} \text { DC Flow }_{f, t-1}+\beta_{2} \text { Non DC Flow }_{f, t-1}+\beta_{3} \text { Perf }_{f, t-1}+\beta_{4} \text { Size }_{f, t-1}+\beta_{5} \text { Fam Size }_{f, t-1} \\
& +\beta_{6} \text { Age }_{f, t-1}+\beta_{7} \operatorname{Exp}_{f, t-1}+\beta_{8} \text { Turn }_{f, t-1}+\beta_{9} \text { DC Ratio }_{f, t-1}+\beta_{t}+\varepsilon_{f, t}
\end{aligned}
$$

To evaluate the performance differences across DC and non-DC flows, we employ a number of different measures of mutual fund return performance: raw fund return per month, objective-adjusted return (where we subtract the mean return of funds in the same objective category from the fund return), style-adjusted return (where we subtract the mean return of funds 
in the same style classification based on the fund holdings), ${ }^{30}$ and alphas based on the Capital Asset Pricing Model, the Fama-French (1993) model, and the Carhart (1997) model. The remaining control variables are the return over the prior year, the logarithm of the total assets of a fund, the logarithm of family size, the logarithm of fund age, the expense ratio, the turnover, and the DC ratio. The specifications also include year-fixed effects and cluster the standard errors by fund.

Table IX presents the results for the tests of flow predictability of fund performance. As the table shows, we find different effects for DC and non-DC flows. For the latter, consistent with Frazzini and Lamont (2008), we find a negative relation between non-DC flows and next year's performance using various performance measures. On the other hand, we do not find a significant relation between DC flows and subsequent fund performance. Furthermore, we also report in the last row the $p$-values of an F-test that investigates whether the coefficients on DC flows equal the coefficients on Non-DC flows. The results indicate that coefficients between the two flow measures differ for all considered performance measures at least at a ten percent significance level.

The insignificant performance predictability results for DC flows are broadly consistent with Berk and Green's (2004) theoretical model. The results indicate that in contrast to retail investors the performance-chasing phenomenon of DC pension plans does not harm their longterm performance prospects.

\section{Conclusions}

In this paper we examine the effects of DC plans on the mutual funds in which they invest. Our results have several implications for the structure of employer-sponsored pension plans and for the mutual fund industry.

\footnotetext{
${ }^{30}$ The holdings-based styles are determined by dividing mutual funds into terciles according to the mean size and mean book-to-market ratio of their holdings. Thus, in each period we obtain nine different fund styles according to the holdings (e.g., small-cap growth, mid-cap growth, large-cap growth, small-cap blend, ..., large-cap value).
} 
First, flows from the assets in DC plans are driven by the menu choices offered by plan sponsors and the decisions of individual plan participants. Contrary to the widely held belief that DC plan assets should be sticky because of plan participants' inertia, we find that the DC money is more volatile, has less autocorrelation and exhibits more flow-performance sensitivity than non-DC money. Moreover, using a sample of plan sponsor data we find that this flowperformance sensitivity is driven by the actions of plan sponsors in dropping poorly performing funds from their menus and adding well-performing funds (and in so doing, moving their participants' assets). These results indicate that the actions of plan sponsors in changing their menus counteract the previously well-documented inertia of plan participants. Further, the differences in flow patterns between DC and non-DC investors that we document suggest that mutual fund management companies can diversify the net flows into their funds by offering the funds to both DC and non-DC investors.

We also examine whether the fund selections of DC plan sponsors and their participants are more discerning than the non-DC investors. Specifically, we test whether mutual fund flows from DC or non-DC investors can predict funds' long-term future return performance. We find that whereas non-DC fund flows predict future performance negatively, DC fund flows have no predictability, suggesting that DC investors are neither smart nor dumb money. This suggests that plan sponsors prevent their participants, on average, from being part of the dumb money crowd.

This role of plan sponsors has implications for the composition of the fund industry, particularly given the growth in defined contribution plans. Ultimately, perhaps, the most important implication is that the presence of DC plans adds increased discipline to mutual fund portfolio management. For example, the increasing flow-performance sensitivities due to the growth of DC assets means that there will be more monitoring of mutual fund management, which implies more managerial effort and fewer agency problems in this part of the delegated money management industry. 


\section{References}

Alexander, Gordon J., Gjergji Cici, and Scott Gibson, 2007, Does Motivation Matter When Assessing Trade Performance? An Analysis of Mutual Funds, Review of Financial Studies 20, 125-150.

Agnew, Julie, Pierluigi Balduzzi, and Annika Sunden, 2003, Portfolio Choice and Trading in a Large 401(k) Plan, American Economic Review 93, 193-215.

Balduzzi, Pierluigi and Jonathan Reuter, 2013, Heterogeneity in Target-Date Funds and the Pension Protection Act of 2006, Working Paper, Boston College.

Barclay, Michael J, Neil D. Pearson, and Michael S. Weisbach, 1998, Open-End Mutual Funds and Capital-Gains Taxes, Journal of Financial Economics 49, 3-43.

Barber, Brad, and Terrance Odean, 2000, Trading Is Hazardous to Your Wealth: The Common Stock Investment Performance of Individual Investors, Journal of Finance 55, 773-806.

Benartzi, Shlomo, and Richard Thaler, 2001, Naïve Diversification Strategies in Defined Contribution Savings Plans, American Economic Review 91, 79-98.

Bergstresser, Daniel and James Poterba, 2002, Do After-Tax Returns Affect Mutual Fund Inflows? Journal of Financial Economics 63, 381-414.

Berk, Jonathan C., and Richard C. Green, 2004, Mutual Fund Flows and Performance in Rational Markets, Journal of Political Economy 112, 1269-1295.

Brown, Jeffrey R., Nellie Liang, and Scott Weisbenner, 2007, Individual Account Investment Options and Portfolio Choice: Behavioral Lessons from 401(k) Plans, Journal of Public Economics 91, 1992-2013.

Brown, Keith C., W. Van Harlow, and Laura T. Starks, 1996, Of Tournaments and Temptations: An Analysis of Managerial Incentives in the Mutual Fund Industry, Journal of Finance 51, 85-110.

Brown, Keith C., and W. Van Harlow, 2012, How Good are the Investment Options Provided by Defined Contribution Plan Sponsors? International Journal of Portfolio Analysis and Management 1, 3-31.

Campbell, John Y., Howell E. Jackson, Brigitte C. Madrian, and Peter Tufano, 2011, Consumer Financial Protection, Journal of Economic Perspectives 25, 91-114.

Carhart, Mark, 1997, On Persistence in Mutual Fund Performance, Journal of Finance, 52, 5782.

Carroll, Gabriel D., James J. Choi, David Laibson, Brigitte C. Madrian, and Andrew Metrick, 2009, Optimal Defaults and Active Decisions, The Quarterly Journal of Economics, 124, 1639-1674.

Chen, Qi, Itay Goldstein, and Wei Jiang, 2010, Payoff Complementarities and Financial Fragility: Evidence from Mutual Fund Outflows, Journal of Financial Economics 97, 239262.

Chevalier, Judith, and Glenn Ellison, 1997. Risk Taking by Mutual Funds as a Response to Incentives. Journal of Political Economy 105, 1167-1200. 
Choi, James J., David Laibson, Brigitte C. Madrian, and Andrew Metrick, 2002, Defined Contribution Pensions: Plan Rules, Participant Decisions, and the Path of Least Resistance, In Tax Policy and the Economy 16, James M. Poterba, ed. (Cambridge, MA: MIT Press).

Choi, James J., David Laibson, Brigitte Madrian, and Andrew Metrick, 2006, Saving for Retirement on the Path of Least Resistance, Behavioral Public Finance (Russell Sage Foundation: E.McCaffrey and J. Slemrod, eds.), 304-351.

Christoffersen, Susan, Christopher Geczy, David Musto, and Adam Reed, 2006, Cross-border Dividend Taxation and the Preferences of Taxable and Non-taxable Investors: Evidence from Canada, Journal of Financial Economics 78, 121-144.

Christoffersen, Susan, and Mikhail Simutin, 2013, Plan Sponsor Oversight and Benchmarking: Effects on Fund Risk-taking and Activeness, Working Paper, University of Toronto.

Cohen, Lauren, and Breno Schmidt, 2009, Attracting Flows by Attracting Big Clients, Journal of Finance 64, 2125-2151.

Coval, Joshua, and Erik Stafford, 2007, Asset Fire Sales (and Purchases) in Equity Markets, Journal of Financial Economics 86, 479-512.

Daniel, Kent, Mark Grinblatt, Sheridan Titman, and Russ Wermers, 1997, Measuring Mutual Fund Performance with Characteristic-Based Benchmarks, Journal of Finance 52, 10351058.

Davis, Gerald F., and E. Han Kim, 2007, Business Ties and Proxy Voting by Mutual Funds, Journal of Financial Economics 85, 552-570.

Del Guercio, Diane, and Paula Tkac, 2002, The Determinants of the Flow of Funds of Managed Portfolios: Mutual Funds versus Pension Funds, Journal of Financial and Quantitative Analysis 37, 523-557.

Del Guercio, Diane and Paula Tkac, 2008, Star Power: The Effect of Morningstar Ratings on Mutual Fund Flow, Journal of Financial and Quantitative Analysis 43, 907-936.

Del Guercio, Diane, and Jonathan Reuter, 2013, Mutual Fund Performance and the Incentive to Generate Alpha, Forthcoming: Journal of Finance.

Deloitte Consulting, 2011, Annual 401(k) Benchmarking Survey: 2011 Edition.

Dickson, Joel, John B. Shoven, and Clemens Sialm, 2000, Tax Externalities of Equity Mutual Funds. National Tax Journal 53, 607-28.

Duflo, Esther, and Emmanuel Saez, 2003, The Role of Information and Social Interactions in Retirement Plan Decisions: Evidence from a Randomized Experiment, The Quarterly Journal of Economics 118, 815-842.

Edelen, Roger, 1999, Investor Flows and the Assessed Performance of Open-End Mutual Funds, Journal of Financial Economics 53, 439-466.

Elton, Edwin J., Martin J. Gruber, and Christopher R. Blake, 2006, The Adequacy of Investment Choices offered by 401(k) Plans, Journal of Public Economics 90, 1299-1314.

Elton, Edwin J., Martin J. Gruber, and Christopher R. Blake, 2007, Participant Reaction and the Performance of Funds Offered by 401(k) Plans, Journal of Financial Intermediation 16, 249-271. 
Evans, Richard, 2010, Mutual Fund Incubation, Journal of Finance 65, 1581-1611.

Fama, Eugene, and Ken French, 1993, Common Risk Factors in the Returns on Stocks and Bonds, Journal of Financial Economics 33, 3-56.

Fama, Eugene, and James D. MacBeth, 1973, Risk, Return, and Equilibrium: Empirical Tests, Journal of Political Economy 81, 607-636.

Frazzini, Andrea, 2006, The Disposition Effect and Underreaction to News, Journal of Finance 61, 2017-2046.

Frazzini, Andrea, and Owen A. Lamont, 2008, Dumb Money: Mutual Fund Flows and the CrossSection of Stock Returns, Journal of Financial Economics 88, 299-322.

Goyal, Amit, and Sunil Wahal, 2008, The Selection and Termination of Investment Management Firms by Plan Sponsors, Journal of Finance 63, 1805-1847.

Grinblatt, Mark, and Matti Keloharju, 2001, What Makes Investors Trade?, Journal of Finance 56, 589-616.

Gruber, Martin J., 1996, Another Puzzle: The Growth in Actively Managed Mutual Funds, Journal of Finance 51, 783-810.

Heisler, Jeffrey, Christopher Knittel, John Neumann, and Scott Stewart, 2007, Why Do Institutional Plan Sponsors Hire and Fire Their Investment Managers? Journal of Business and Economic Studies 13: 88-115

Huang, Jennifer, Kelsey D. Wei, and Hong Yan, 2007, Participation Costs and the Sensitivity of Fund Flows to Past Performance, Journal of Finance 62, 1273-1311.

Huang, Jennifer, Kelsey D. Wei, and Hong Yan, 2012, Investor Learning and Mutual Fund Flows, Working Paper, University of Texas at Austin.

Huberman, Gur, and Wei Jiang, 2006, Offering versus Choice in 401(k) Plans: Equity Exposure and Number of Funds, Journal of Finance 61, 763-801.

Investment Company Institute, 2012, The Investment Company Fact Book 52.

Ivković, Zoran, and Scott Weisbenner, 2009, Individual Investor Mutual Fund Flows, Journal of Financial Economics 92, 223-237.

Khorana, Ajay, and Henri Servaes, 1999, The Determinants of Mutual Fund Starts, Review of Financial Studies 12, 1043-1074.

Kim, Min S., 2011, Changes in Mutual Fund Flows and Managerial Incentives, Working Paper, University of New South Wales.

Lakonishok, Josef, Andrei Shleifer, and Robert Vishny, 1992, The Structure and Performance of the Money Management Industry, Brookings Papers: Microeconomics, 339-379.

Lou, Dong, 2012, A Flow-Based Explanation for Return Predictability, Review of Financial Studies 25, 3457-3489.

Madrian, Brigitte, and Dennis F. Shea, 2001, The Power of Suggestion: Inertia in 401(k) Participation and Savings Behavior, Quarterly Journal of Economics 116, 1149-1187. 
McFarland, Brendan, 2013, DB Versus DC Investment Returns: The 2009-2011 Update, Towers Watson Insider.

Pool, Veronika, Clemens Sialm, and Irina Stefanescu, 2013, It Pays to Set the Menu: 401(k) Investment Options in Mutual Funds, Working Paper, Indiana University and University of Texas at Austin.

Rauh, Joshua, 2006, Own Company Stock in Defined Contribution Pension Plans: A Takeover Defense? Journal of Financial Economics 81, 379-410.

Rydqvist, Kristian, Ilya A. Strebulaev, and Joshua D. Spizman, 2013, Policy and Ownership of Equity Securities, Forthcoming: Journal of Financial Economics.

Sialm, Clemens, and Laura Starks, 2012, Mutual Fund Tax Clienteles, Journal of Finance 67, 1397-1422.

Sirri, Erik, and Peter Tufano, 1998, Costly Search and Mutual Fund Flows, Journal of Finance 53, 1589-1622.

Stewart, Scott, John Neumann, Christopher Knittel, and Jeffrey Heisler, 2009, Absence of Value: An Analysis of Investment Allocation Decisions by Institutional Plan Sponsors, Financial Analysts Journal 65, 34-51.

Tang, Ning, Olivia S. Mitchell, Gary R. Mottola, and Stephen P. Utkus, 2010, The Efficiency of Sponsor and Participant Portfolio Choices in 401(k) Plans, Journal of Public Economics 1112, 1073-1085.

Wermers, Russ, 2000, Mutual Fund Performance: An Empirical Decomposition into StockPicking Talent, Style, Transaction Costs, and Expenses, Journal of Finance 55, 1655-1702.

Wermers, Russ, 2003, Is Money Really 'Smart'? New Evidence on the Relation between Mutual Fund Flows, Manager Behavior, and Performance Persistence, Working Paper, University of Maryland.

Zheng, Lu, 1999, Is Money Smart? A Study of Mutual Fund Investors' Fund Selection Ability, Journal of Finance 54, 901-933. 


\section{Figure 1}

\section{Flow-Performance Relation for Percentile Performance Portfolios of DC and Non-DC Assets}

This figure shows the flow-performance relation for DC and non-DC assets. The dots represent the average flows for 100 performance groups, where the remaining covariates are evaluated at their sample means. Diamonds correspond to DC flows and circles correspond to non-DC flows. The solid curves show the least-squares cubic relations.

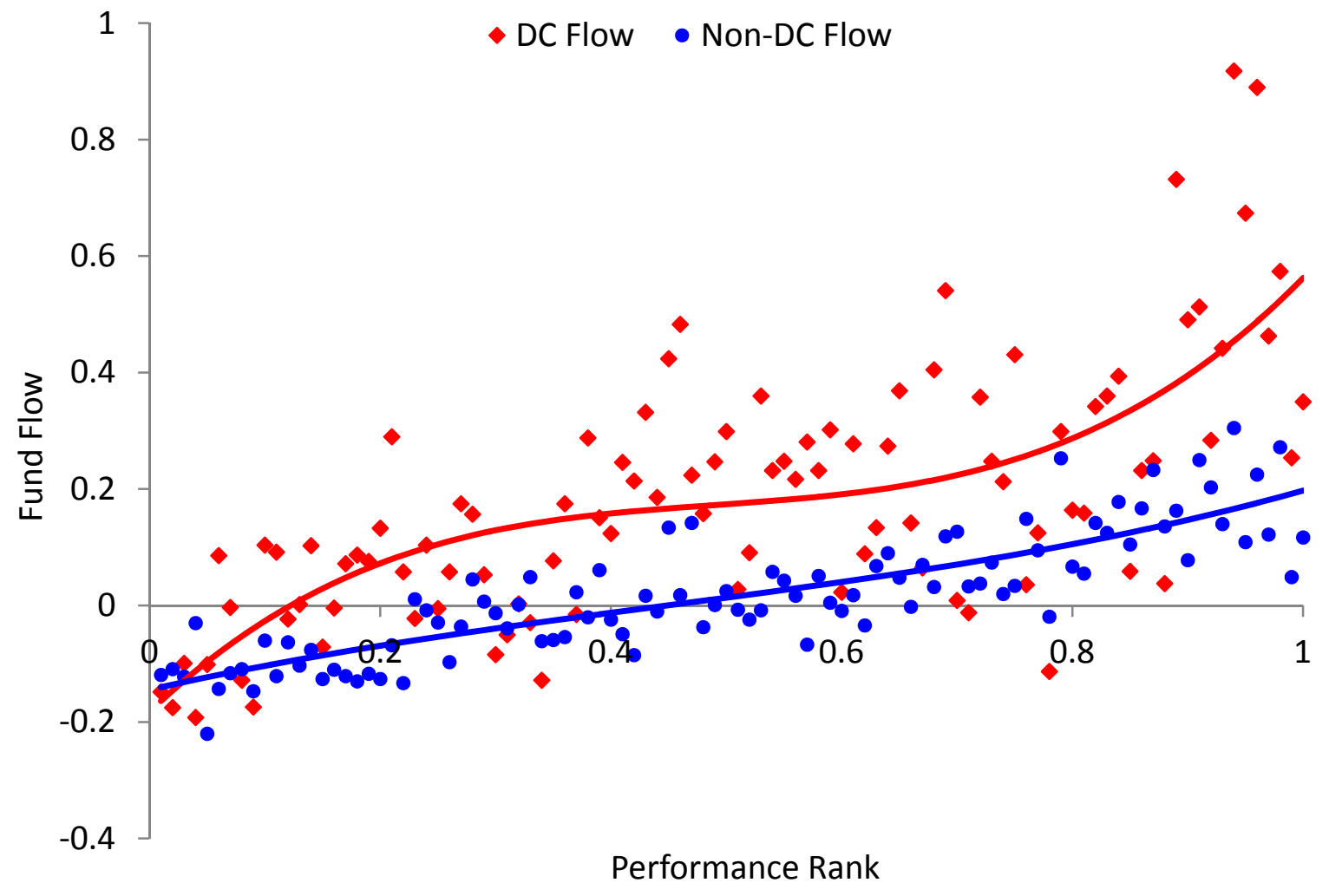


Figure 2

Piecewise Linear Flow-Performance Relation for Percentile Performance Portfolios of DC Assets and Non-DC Assets

This figure shows the flow-performance relation for DC and non-DC assets. The lines represent the piecewise linear relation following Sirri and Tufano (1998), as summarized in Table III.

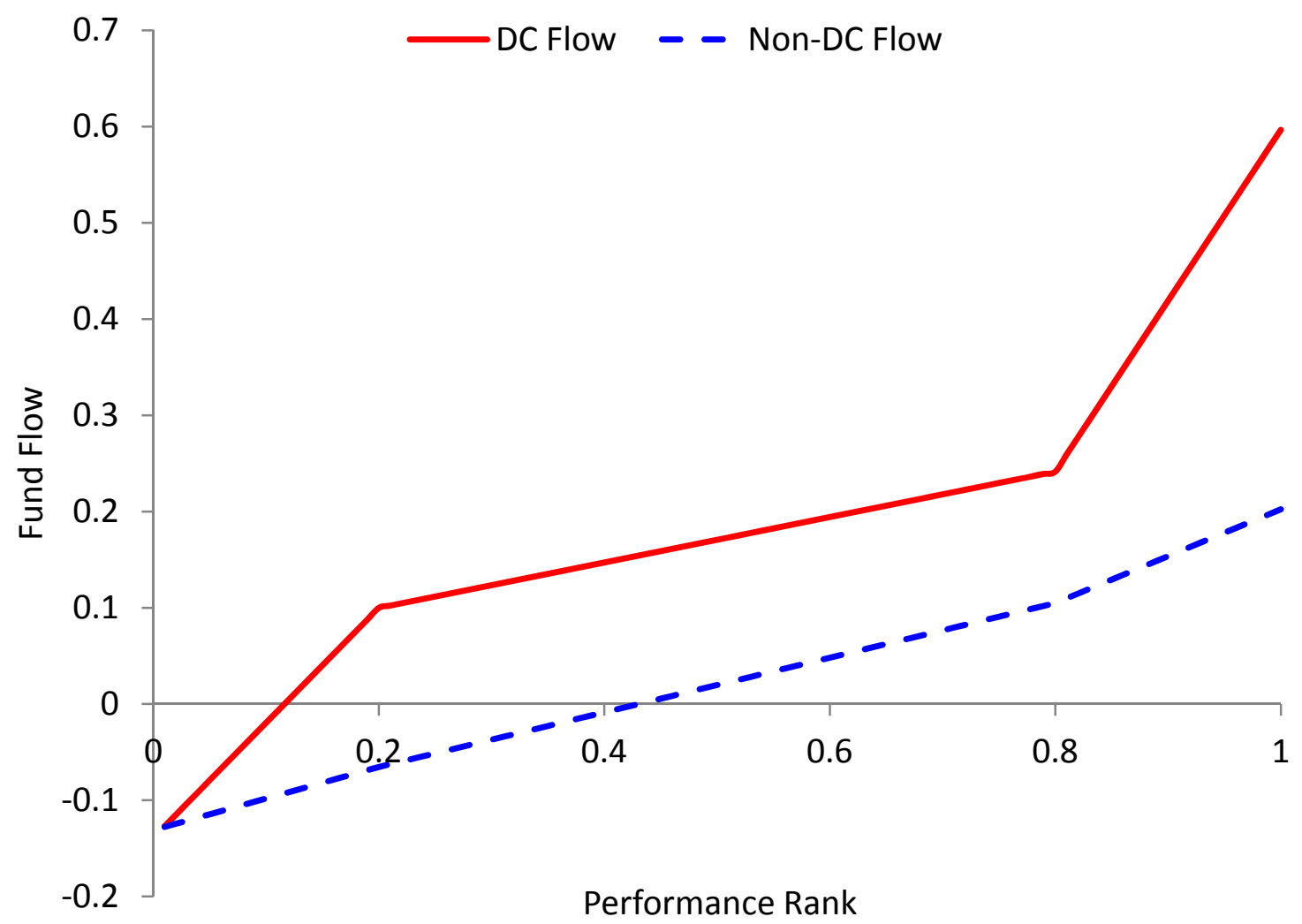


Figure 3

Plan Flows and Participant Flows by Performance Percentiles

This figure shows the flow-performance relation for total plan flows and participant flows based on 11-K filings of $401(\mathrm{k})$ plans. The dots represent the average flows for 100 performance groups, where the remaining covariates are evaluated at their sample means. Diamonds correspond to total plan flows and circles correspond to participant flows. Participant flows are computed as the difference between total flows and sponsor flows (i.e., flows driven by addition and deletion decisions in 401(k) menus). The solid curves show the least-squares cubic relations.

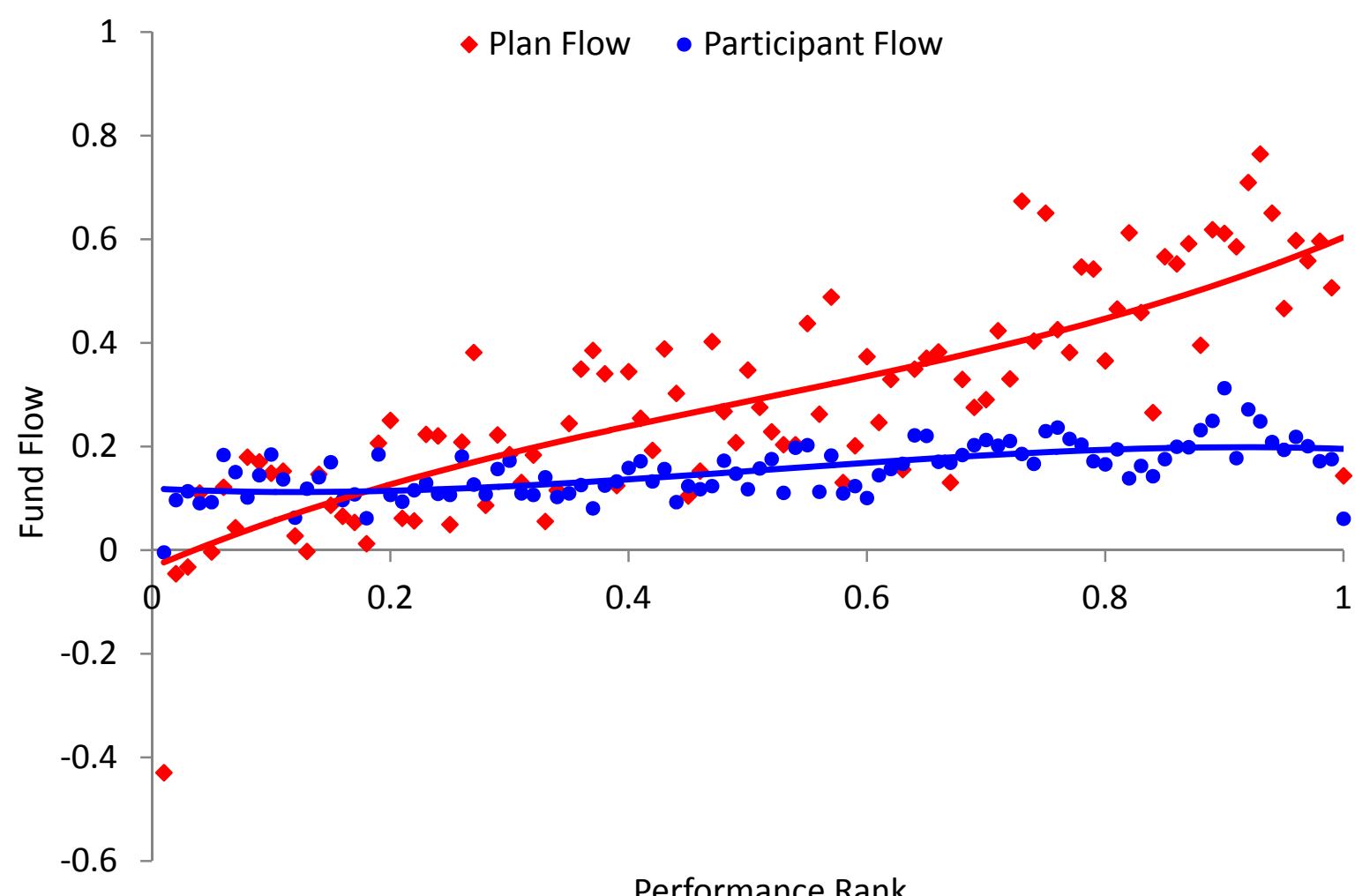

Performance Rank 


\section{Table I \\ Summary Statistics}

This table provides the summary statistics for the sample of mutual funds over the 1996-2009 period. The DC ratio is the percentage of the fund assets held by defined contribution accounts at the end of the year. The fund size (Total Net Assets), family size, age, expenses, turnover, and fund returns are obtained from the CRSP mutual fund database. The annual DC flow is the percentage flow of DC assets based on the annual surveys by Pensions \& Investments, and the annual Non-DC flow is the percentage flow based on the difference between total net assets and DC assets. The annual plan, plan sponsor, and plan participant flows are based on annual Form 11-K filings by corporate DC plans.

Panel A: Variable Distributions

\begin{tabular}{lrrrrr}
\hline Name & Mean & Std. Dev. & Quartile 1 & Median & Quartile 3 \\
\hline & & & & & \\
DC Ratio (in \% of Fund Size) & 25.38 & 22.00 & 8.50 & 19.85 & 35.52 \\
Fund Size (in M\$) & 3,931 & 10,289 & 269 & 967 & 3,122 \\
Family Size (in M\$) & 57,242 & 113,605 & 5,746 & 14,594 & 41,176 \\
Age (in Years) & 16.33 & 15.46 & 7.00 & 11.00 & 19.00 \\
Expense Ratio (in \% per Year) & 1.16 & 0.45 & 0.90 & 1.16 & 1.42 \\
Turnover (in \% per Year ) & 78.26 & 82.60 & 30.51 & 61.00 & 103.00 \\
Fund Return (in \% per Year) & 6.76 & 24.96 & -9.06 & 9.59 & 21.87 \\
DC Flow (in \% per Year) & 32.00 & 119.34 & -20.78 & -0.23 & 32.76 \\
Non-DC Flow (in \% per Year) & 6.65 & 44.37 & -16.14 & -3.96 & 14.06 \\
Plan Flow (\% per Year) & 22.27 & 84.76 & -15.86 & 3.56 & 36.85 \\
Plan Sponsor Flow (\% per Year) & 9.68 & 74.12 & -12.27 & 0.00 & 7.30 \\
Plan Participant Flow (\% per Year) & 12.59 & 25.88 & -1.85 & 3.35 & 17.35 \\
Number of Observations & 5,808 & & & & \\
\hline
\end{tabular}

Panel B: Correlations

\begin{tabular}{lccccccccccc}
\hline Variable & \multicolumn{1}{c}{$(1)$} & $(2)$ & $(3)$ & $(4)$ & $(5)$ & $(6)$ & (7) & (8) & (9) & (10) & (11) \\
\hline (1) DC Ratio & 1.00 & & & & & & & & & & \\
(2) Fund Size & 0.12 & 1.00 & & & & & & & & & \\
(3) Family Size & 0.26 & 0.54 & 1.00 & & & & & & & & \\
(4) Age & -0.11 & 0.29 & 0.18 & 1.00 & & & & & & & \\
(5) Expense Ratio & -0.32 & -0.29 & -0.35 & -0.13 & 1.00 & & & & & & \\
(6) Turnover & -0.10 & -0.08 & -0.07 & -0.02 & 0.15 & 1.00 & & & & & \\
(7) Fund Return & 0.00 & 0.01 & 0.02 & -0.01 & 0.00 & -0.01 & 1.00 & & & & \\
(8) DC Flow & -0.02 & -0.07 & -0.08 & -0.13 & 0.10 & 0.01 & 0.03 & 1.00 & & & \\
(9) Non-DC Flow & -0.07 & -0.04 & -0.02 & -0.15 & 0.00 & 0.03 & 0.06 & 0.23 & 1.00 & & \\
(10) Plan Flow & -0.03 & -0.03 & -0.03 & -0.09 & 0.02 & 0.03 & 0.02 & 0.26 & 0.26 & 1.00 & \\
(11) Plan Sponsor Flow & -0.02 & -0.01 & -0.01 & -0.07 & 0.00 & 0.03 & 0.01 & 0.22 & 0.23 & 0.95 & 1.00 \\
(12) Plan Participant Flow & -0.05 & -0.07 & -0.07 & -0.12 & 0.08 & 0.03 & 0.05 & 0.21 & 0.19 & 0.54 & 0.26 \\
\hline
\end{tabular}




\section{Table II}

\section{Relation Between Flow Variability and Fund Characteristics}

This table summarizes the coefficients of a regression of moments of flows on fund characteristics. The dependent variables are defined as the standard deviation and the autocorrelation of the annual DC and non-DC flows over the lifetime of a fund, requiring that funds have at least five annual observations. The independent variables include an indicator variable for DC or non-DC flows, and the initial DC or non-DC size, and other initial fund characteristics. All continuous independent variables are demeaned. The standard errors are reported in parentheses. ${ }^{*}, * *$, and $* * *$ denote estimates that are statistically different from zero at the 10,5 , and 1 percent significance levels.

\begin{tabular}{|c|c|c|c|c|c|c|}
\hline \multirow[b]{2}{*}{ Constant } & \multicolumn{3}{|c|}{ Standard Deviation of Flow } & \multicolumn{3}{|c|}{ Autocorrelation of Flow } \\
\hline & $\begin{array}{l}0.332^{* * *} \\
(0.012)\end{array}$ & $\begin{array}{l}0.549^{* * *} \\
(0.023)\end{array}$ & $\begin{array}{l}0.439 * * * \\
(0.018)\end{array}$ & $\begin{array}{l}0.093^{* * *} \\
(0.023)\end{array}$ & $\begin{array}{l}0.080^{* * *} \\
(0.029)\end{array}$ & $\begin{array}{c}0.063^{*} \\
(0.036)\end{array}$ \\
\hline DC Indicator & $\begin{array}{l}0.522^{* * * *} \\
(0.033)\end{array}$ & $\begin{array}{l}0.212^{* * *} \\
(0.031)\end{array}$ & $\begin{array}{l}0.310^{* * *} \\
(0.031)\end{array}$ & $\begin{array}{l}-0.138^{* * * *} \\
(0.026)\end{array}$ & $\begin{array}{l}-0.127^{* * * *} \\
(0.034)\end{array}$ & $\begin{array}{l}-0.114^{* * *} \\
(0.041)\end{array}$ \\
\hline Log Size & & $\begin{array}{l}-0.163^{* * *} \\
(0.014)\end{array}$ & $\begin{array}{l}-0.077^{* * *} \\
(0.009)\end{array}$ & & $\begin{array}{c}0.005 \\
(0.011)\end{array}$ & $\begin{array}{c}0.018 \\
(0.019)\end{array}$ \\
\hline Log Family Size & & $\begin{array}{l}0.035^{* * *} \\
(0.012)\end{array}$ & $\begin{array}{l}0.021^{* * *} \\
(0.008)\end{array}$ & & $\begin{array}{c}0.027^{*} \\
(0.014)\end{array}$ & $\begin{array}{c}0.014 \\
(0.017)\end{array}$ \\
\hline Log Age & & $\begin{array}{c}0.033 \\
(0.026)\end{array}$ & $\begin{array}{l}-0.039 * * * \\
(0.015)\end{array}$ & & $\begin{array}{l}-0.026 \\
(0.022)\end{array}$ & $\begin{array}{l}-0.023 \\
(0.033)\end{array}$ \\
\hline Expense Ratio & & $\begin{array}{l}1.071^{* *} \\
(0.460)\end{array}$ & $\begin{array}{c}0.290 \\
(0.261)\end{array}$ & & $\begin{array}{l}-0.471 \\
(0.501)\end{array}$ & $\begin{array}{l}-0.252 \\
(0.656)\end{array}$ \\
\hline Turnover & & $\begin{array}{l}-0.006 \\
(0.014)\end{array}$ & $\begin{array}{c}0.015 \\
(0.010)\end{array}$ & & $\begin{array}{l}0.029 * * * \\
(0.011)\end{array}$ & $\begin{array}{c}0.011 \\
(0.016)\end{array}$ \\
\hline DC x Log Size & & & $\begin{array}{l}-0.117 * * * \\
(0.018)\end{array}$ & & & $\begin{array}{l}-0.020 \\
(0.021)\end{array}$ \\
\hline DC x Log Family Size & & & $\begin{array}{c}0.005 \\
(0.018)\end{array}$ & & & $\begin{array}{c}0.026 \\
(0.019)\end{array}$ \\
\hline DC x Log Age & & & $\begin{array}{l}0.091^{* *} \\
(0.040)\end{array}$ & & & $\begin{array}{l}-0.012 \\
(0.038)\end{array}$ \\
\hline DC $x$ Expense Ratio & & & $\begin{array}{c}1.338^{*} \\
(0.785)\end{array}$ & & & $\begin{array}{l}-0.532 \\
(0.875)\end{array}$ \\
\hline DC x Turnover & & & $\begin{array}{l}-0.038^{* *} \\
(0.019)\end{array}$ & & & $\begin{array}{c}0.036 \\
(0.024)\end{array}$ \\
\hline Observations & 1,032 & 987 & 987 & 1,032 & 987 & 987 \\
\hline R-Squared & 0.162 & 0.390 & 0.420 & 0.018 & 0.030 & 0.035 \\
\hline
\end{tabular}




\section{Table III}

Piecewise Linear Panel Regressions of DC and Non-DC Flows

This table summarizes the coefficients of a piecewise linear panel regression of DC and non-DC asset flows on fund variables. Low, Mid, and High represent the funds' ranked return performance where $\operatorname{Low}_{f, t}=\min \left(\operatorname{Rank}_{f, t}, 0.2\right), \operatorname{Mid}_{f, t}=\min \left(\operatorname{Rank}_{f, t}-\operatorname{Low}_{f, t}, 0.6\right)$, and $\operatorname{High}_{f, t}=$ $\left(\operatorname{Rank}_{f, t}-\operatorname{Low}_{f, t}-\operatorname{Mid}_{f, t}\right)$. The other variables are characteristics of the fund. The standard errors of the coefficients are reported in parentheses and adjusted for clustering at the fund level. The regressions also include time-fixed effects. ${ }^{*},{ }^{* *}$, and ${ }^{* * *}$ denote estimates that are statistically different from zero at the 10,5 , and 1 percent significance levels.

\begin{tabular}{|c|c|c|c|c|c|c|}
\hline & \multicolumn{3}{|c|}{1 Year Prior Performance } & \multicolumn{3}{|c|}{5 Year Prior Performance } \\
\hline & DC Flow & $\begin{array}{c}\text { Non- } \\
\text { DC Flow }\end{array}$ & Difference & DC Flow & $\begin{array}{c}\text { Non- } \\
\text { DC Flow }\end{array}$ & Difference \\
\hline Low & $\begin{array}{l}1.194^{* * *} \\
(0.377)\end{array}$ & $\begin{array}{l}0.328^{* *} \\
(0.142)\end{array}$ & $\begin{array}{l}0.866 * * \\
(0.374)\end{array}$ & $\begin{array}{l}0.845^{* *} \\
(0.334)\end{array}$ & $\begin{array}{c}0.096 \\
(0.166)\end{array}$ & $\begin{array}{l}0.749 * * \\
(0.330)\end{array}$ \\
\hline Mid & $\begin{array}{l}0.236^{* * *} \\
(0.086)\end{array}$ & $\begin{array}{l}0.284^{* * *} \\
(0.037)\end{array}$ & $\begin{array}{l}-0.049 \\
(0.090)\end{array}$ & $\begin{array}{l}0.421^{* * * *} \\
(0.082)\end{array}$ & $\begin{array}{l}0.281^{* * * *} \\
(0.036)\end{array}$ & $\begin{array}{c}0.140 * \\
(0.083)\end{array}$ \\
\hline High & $\begin{array}{l}1.776^{* * *} \\
(0.497)\end{array}$ & $\begin{array}{l}0.487^{* * *} \\
(0.180)\end{array}$ & $\begin{array}{l}1.289 * * * \\
(0.476)\end{array}$ & $\begin{array}{c}0.619 * \\
(0.329)\end{array}$ & $\begin{array}{c}0.102 \\
(0.154)\end{array}$ & $\begin{array}{c}0.517 \\
(0.334)\end{array}$ \\
\hline Log DC Size & $\begin{array}{l}-0.136^{* * *} \\
(0.017)\end{array}$ & $\begin{array}{c}0.007 \\
(0.006)\end{array}$ & $\begin{array}{l}-0.143^{* * *} \\
(0.016)\end{array}$ & $\begin{array}{c}-0.125^{* * *} \\
(0.018)\end{array}$ & $\begin{array}{c}0.006 \\
(0.006)\end{array}$ & $\begin{array}{l}-0.132 * * * \\
(0.016)\end{array}$ \\
\hline Log Non-DC Size & $\begin{array}{l}0.041^{* *} \\
(0.016)\end{array}$ & $\begin{array}{l}-0.070^{* * *} \\
(0.009)\end{array}$ & $\begin{array}{l}0.111^{* * *} \\
(0.018)\end{array}$ & $\begin{array}{c}0.020 \\
(0.014)\end{array}$ & $\begin{array}{l}-0.069 * * * \\
(0.010)\end{array}$ & $\begin{array}{l}0.089 * * * \\
(0.016)\end{array}$ \\
\hline Log Family Size & $\begin{array}{l}0.039 * * * \\
(0.014)\end{array}$ & $\begin{array}{l}0.039 * * * \\
(0.007)\end{array}$ & $\begin{array}{c}0.000 \\
(0.013)\end{array}$ & $\begin{array}{l}0.042^{* * *} \\
(0.014)\end{array}$ & $\begin{array}{l}0.032^{* * *} \\
(0.007)\end{array}$ & $\begin{array}{c}0.010 \\
(0.013)\end{array}$ \\
\hline Log Age & $\begin{array}{l}-0.037 \\
(0.024)\end{array}$ & $\begin{array}{c}0.003 \\
(0.010)\end{array}$ & $\begin{array}{l}-0.040^{*} \\
(0.022)\end{array}$ & $\begin{array}{l}-0.005 \\
(0.024)\end{array}$ & $\begin{array}{c}0.020^{*} \\
(0.011)\end{array}$ & $\begin{array}{l}-0.025 \\
(0.024)\end{array}$ \\
\hline Expense Ratio & $\begin{array}{l}-0.471 \\
(0.551)\end{array}$ & $\begin{array}{l}-0.223 \\
(0.219)\end{array}$ & $\begin{array}{l}-0.248 \\
(0.511)\end{array}$ & $\begin{array}{l}-0.152 \\
(0.509)\end{array}$ & $\begin{array}{l}-0.380 * \\
(0.227)\end{array}$ & $\begin{array}{c}0.229 \\
(0.481)\end{array}$ \\
\hline Turnover & $\begin{array}{l}-0.026 \\
(0.019)\end{array}$ & $\begin{array}{l}-0.018^{* *} \\
(0.008)\end{array}$ & $\begin{array}{l}-0.007 \\
(0.016)\end{array}$ & $\begin{array}{l}-0.042 * * \\
(0.018)\end{array}$ & $\begin{array}{l}-0.019 * \\
(0.011)\end{array}$ & $\begin{array}{l}-0.023 \\
(0.018)\end{array}$ \\
\hline Volatility & $\begin{array}{c}1.026 \\
(0.870)\end{array}$ & $\begin{array}{c}0.009 \\
(0.317)\end{array}$ & $\begin{array}{c}1.017 \\
(0.857)\end{array}$ & $\begin{array}{c}0.499 \\
(0.963)\end{array}$ & $\begin{array}{l}-0.567 \\
(0.477)\end{array}$ & $\begin{array}{c}1.066 \\
(0.951)\end{array}$ \\
\hline Style Flow & $\begin{array}{c}0.359 \\
(0.324)\end{array}$ & $\begin{array}{l}0.282^{* *} \\
(0.132)\end{array}$ & $\begin{array}{c}0.077 \\
(0.295)\end{array}$ & $\begin{array}{c}0.051 \\
(0.319)\end{array}$ & $\begin{array}{c}0.248^{*} \\
(0.138)\end{array}$ & $\begin{array}{l}-0.197 \\
(0.300)\end{array}$ \\
\hline Observations & 3,851 & 3,851 & 3,851 & 3,249 & 3,249 & 3,249 \\
\hline R-squared & 0.098 & 0.124 & 0.064 & 0.081 & 0.089 & 0.054 \\
\hline
\end{tabular}




\section{Table IV}

\section{Piecewise Linear Panel Regression with Different Performance Benchmark Measures}

This table summarizes the coefficients of a piecewise linear panel regression of DC and non-DC asset flows on fund variables. Low, Mid, and High represent the funds' ranked return performance where $\operatorname{Low}_{f, t}=\min \left(\operatorname{Rank}_{f, t}, 0.2\right), \operatorname{Mid}_{f, t}=\min \left(\operatorname{Rank}_{f, t}-\operatorname{Low}_{f, t}, 0.6\right)$, and $\operatorname{High}_{f, t}=\left(\operatorname{Rank}_{f, t}-\operatorname{Low}_{f, t}-\operatorname{Mid}_{f, t}\right)$. The other variables are characteristics of the fund. The performance measures correspond to the objective code-adjusted performance, the style-adjusted performance, and the Carhart-adjusted performance. The standard errors of the coefficients are reported in parentheses and adjusted for clustering at the fund level. The regressions also include time-fixed effects. ${ }^{*}, * *$, and $* * *$ denote estimates that are statistically different from zero at the 10,5 , and 1 percent significance levels. 
Table IV (Cont.)

\begin{tabular}{|c|c|c|c|c|c|c|c|c|c|}
\hline & \multicolumn{3}{|c|}{ Objective Code Adjusted Performance } & \multicolumn{3}{|c|}{ Style Adjusted Performance } & \multicolumn{3}{|c|}{ Carhart-Adjusted Performance } \\
\hline & DC Flow & $\begin{array}{c}\text { Non- } \\
\text { DC Flow } \\
\end{array}$ & Difference & DC Flow & $\begin{array}{c}\text { Non- } \\
\text { DC Flow }\end{array}$ & Difference & DC Flow & $\begin{array}{c}\text { Non- } \\
\text { DC Flow }\end{array}$ & Difference \\
\hline Low & $\begin{array}{l}1.040 * * * \\
(0.389)\end{array}$ & $\begin{array}{l}0.379 * * \\
(0.150)\end{array}$ & $\begin{array}{c}0.661 * \\
(0.394)\end{array}$ & $\begin{array}{l}1.219 * * * \\
(0.420)\end{array}$ & $\begin{array}{c}0.088 \\
(0.161)\end{array}$ & $\begin{array}{l}1.130 * * \\
(0.448)\end{array}$ & $\begin{array}{l}0.927 * * \\
(0.406)\end{array}$ & $\begin{array}{c}0.073 \\
(0.168)\end{array}$ & $\begin{array}{l}0.854^{* *} \\
(0.426)\end{array}$ \\
\hline Mid & $\begin{array}{l}0.237 * * * \\
(0.090)\end{array}$ & $\begin{array}{l}0.273^{* * *} \\
(0.036)\end{array}$ & $\begin{array}{l}-0.036 \\
(0.095)\end{array}$ & $\begin{array}{c}0.189 * \\
(0.097)\end{array}$ & $\begin{array}{l}0.275^{* * *} \\
(0.035)\end{array}$ & $\begin{array}{l}-0.086 \\
(0.100)\end{array}$ & $\begin{array}{c}0.138 \\
(0.100)\end{array}$ & $\begin{array}{l}0.281^{* * *} \\
(0.037)\end{array}$ & $\begin{array}{l}-0.143 \\
(0.106)\end{array}$ \\
\hline High & $\begin{array}{l}1.736 * * * \\
(0.473)\end{array}$ & $\begin{array}{l}0.504^{* * *} \\
(0.181)\end{array}$ & $\begin{array}{l}1.232^{* * *} \\
(0.455)\end{array}$ & $\begin{array}{l}1.390 * * * \\
(0.470)\end{array}$ & $\begin{array}{l}0.415^{* *} \\
(0.180)\end{array}$ & $\begin{array}{c}0.975^{* *} \\
(0.475)\end{array}$ & $\begin{array}{l}1.625^{* * *} \\
(0.504)\end{array}$ & $\begin{array}{c}0.290 \\
(0.188)\end{array}$ & $\begin{array}{l}1.336 * * * \\
(0.474)\end{array}$ \\
\hline Log DC Size & $\begin{array}{l}-0.136 * * * \\
(0.017)\end{array}$ & $\begin{array}{c}0.006 \\
(0.006)\end{array}$ & $\begin{array}{l}-0.142^{* * *} \\
(0.016)\end{array}$ & $\begin{array}{l}-0.144^{* * *} \\
(0.018)\end{array}$ & $\begin{array}{c}0.004 \\
(0.006)\end{array}$ & $\begin{array}{l}-0.148^{* * *} \\
(0.017)\end{array}$ & $\begin{array}{l}-0.130 * * * \\
(0.018)\end{array}$ & $\begin{array}{c}0.011^{*} \\
(0.006)\end{array}$ & $\begin{array}{l}-0.142^{* * *} \\
(0.017)\end{array}$ \\
\hline Log Non-DC Size & $\begin{array}{l}0.041^{* *} \\
(0.017)\end{array}$ & $\begin{array}{l}-0.070 * * * \\
(0.009)\end{array}$ & $\begin{array}{l}0.111^{* * *} \\
(0.018)\end{array}$ & $\begin{array}{c}0.037 * * \\
(0.018)\end{array}$ & $\begin{array}{l}-0.074^{* * *} \\
(0.009)\end{array}$ & $\begin{array}{l}0.111^{* * *} \\
(0.019)\end{array}$ & $\begin{array}{c}0.030 * \\
(0.017)\end{array}$ & $\begin{array}{l}-0.073 * * * \\
(0.009)\end{array}$ & $\begin{array}{l}0.103^{* * *} \\
(0.019)\end{array}$ \\
\hline Log Family Size & $\begin{array}{l}0.039 * * * \\
(0.014)\end{array}$ & $\begin{array}{l}0.039 * * * \\
(0.007)\end{array}$ & $\begin{array}{c}0.000 \\
(0.013)\end{array}$ & $\begin{array}{l}0.045^{* * *} \\
(0.015)\end{array}$ & $\begin{array}{l}0.044^{* * *} \\
(0.007)\end{array}$ & $\begin{array}{c}0.002 \\
(0.013)\end{array}$ & $\begin{array}{l}0.040^{* * *} \\
(0.015)\end{array}$ & $\begin{array}{l}0.037 * * * \\
(0.007)\end{array}$ & $\begin{array}{c}0.003 \\
(0.014)\end{array}$ \\
\hline Log Age & $\begin{array}{l}-0.037 \\
(0.024)\end{array}$ & $\begin{array}{c}0.004 \\
(0.010)\end{array}$ & $\begin{array}{l}-0.041^{*} \\
(0.023)\end{array}$ & $\begin{array}{l}-0.047 * \\
(0.024)\end{array}$ & $\begin{array}{l}-0.006 \\
(0.010)\end{array}$ & $\begin{array}{l}-0.041 * \\
(0.022)\end{array}$ & $\begin{array}{l}-0.036 \\
(0.027)\end{array}$ & $\begin{array}{l}-0.001 \\
(0.010)\end{array}$ & $\begin{array}{l}-0.035 \\
(0.026)\end{array}$ \\
\hline Expenses & $\begin{array}{l}-0.401 \\
(0.547)\end{array}$ & $\begin{array}{l}-0.191 \\
(0.218)\end{array}$ & $\begin{array}{l}-0.210 \\
(0.506)\end{array}$ & $\begin{array}{l}-0.416 \\
(0.556)\end{array}$ & $\begin{array}{l}-0.171 \\
(0.221)\end{array}$ & $\begin{array}{l}-0.245 \\
(0.513)\end{array}$ & $\begin{array}{l}-0.108 \\
(0.579)\end{array}$ & $\begin{array}{c}0.076 \\
(0.226)\end{array}$ & $\begin{array}{l}-0.185 \\
(0.536)\end{array}$ \\
\hline Turnover & $\begin{array}{l}-0.024 \\
(0.019)\end{array}$ & $\begin{array}{l}-0.018 * * \\
(0.008)\end{array}$ & $\begin{array}{l}-0.006 \\
(0.016)\end{array}$ & $\begin{array}{l}-0.030 \\
(0.019)\end{array}$ & $\begin{array}{l}-0.022^{* * *} \\
(0.008)\end{array}$ & $\begin{array}{l}-0.008 \\
(0.017)\end{array}$ & $\begin{array}{l}-0.029 \\
(0.020)\end{array}$ & $\begin{array}{l}-0.016 * \\
(0.008)\end{array}$ & $\begin{array}{l}-0.014 \\
(0.018)\end{array}$ \\
\hline Volatility & $\begin{array}{l}-0.099 \\
(1.304)\end{array}$ & $\begin{array}{l}-0.506 \\
(0.468)\end{array}$ & $\begin{array}{c}0.408 \\
(1.284)\end{array}$ & $\begin{array}{c}0.096 \\
(1.914)\end{array}$ & $\begin{array}{l}-0.857^{*} \\
(0.506)\end{array}$ & $\begin{array}{c}0.953 \\
(1.881)\end{array}$ & $\begin{array}{l}-0.017 * \\
(0.008)\end{array}$ & $\begin{array}{l}-0.016^{* * *} \\
(0.003)\end{array}$ & $\begin{array}{l}-0.001 \\
(0.008)\end{array}$ \\
\hline Style Flow & $\begin{array}{c}0.499 \\
(0.322)\end{array}$ & $\begin{array}{l}0.389 * * * \\
(0.132)\end{array}$ & $\begin{array}{c}0.111 \\
(0.293)\end{array}$ & $\begin{array}{l}0.788 * * * \\
(0.229)\end{array}$ & $\begin{array}{l}0.661^{* * *} \\
(0.089)\end{array}$ & $\begin{array}{c}0.127 \\
(0.214)\end{array}$ & $\begin{array}{c}0.439 \\
(0.331)\end{array}$ & $\begin{array}{l}0.332 * * \\
(0.131)\end{array}$ & $\begin{array}{c}0.107 \\
(0.301)\end{array}$ \\
\hline Observations & 3,851 & 3,851 & 3,851 & 3,780 & 3,780 & 3,780 & 3,408 & 3,408 & 3,408 \\
\hline R-squared & 0.097 & 0.125 & 0.063 & 0.098 & 0.128 & 0.064 & 0.089 & 0.110 & 0.063 \\
\hline
\end{tabular}




\section{Table V}

Piecewise Linear Panel Regressions of DC and Non-DC Flows for Different Subperiods This table summarizes the coefficients of a piecewise linear panel regression of DC and non-DC asset flows on fund variables. Low, Mid, and High represent the funds' ranked return performance where $\operatorname{Low}_{f, t}=\min \left(\operatorname{Rank}_{f, t}, 0.2\right), \operatorname{Mid}_{f, t}=\min \left(\operatorname{Rank}_{f, t}-\operatorname{Low}_{f, t}, 0.6\right)$, and $\operatorname{High}_{f, t}=$ $\left(\operatorname{Rank}_{f, t}-\operatorname{Low}_{f, t}-\operatorname{Mid}_{f, t}\right)$. The other variables are characteristics of the fund. The standard errors of the coefficients are reported in parentheses and adjusted for clustering at the fund level. The regressions also include time-fixed effects. *, ${ }^{* *}$, and ${ }^{* * *}$ denote estimates that are statistically different from zero at the 10,5 , and 1 percent significance levels.

\begin{tabular}{|c|c|c|c|c|c|c|}
\hline & \multicolumn{3}{|c|}{ 1996-2002 } & \multicolumn{3}{|c|}{ 2003-2009 } \\
\hline & DC Flow & $\begin{array}{c}\text { Non- } \\
\text { DC Flow }\end{array}$ & Difference & DC Flow & $\begin{array}{c}\text { Non- } \\
\text { DC Flow }\end{array}$ & Difference \\
\hline Low & $\begin{array}{c}0.660 \\
(0.630)\end{array}$ & $\begin{array}{c}0.318 \\
(0.223)\end{array}$ & $\begin{array}{c}0.343 \\
(0.649)\end{array}$ & $\begin{array}{l}1.546^{* * *} \\
(0.473)\end{array}$ & $\begin{array}{l}0.410^{* *} \\
(0.196)\end{array}$ & $\begin{array}{l}1.136^{* *} \\
(0.462)\end{array}$ \\
\hline Mid & $\begin{array}{l}0.416^{* * *} \\
(0.141)\end{array}$ & $\begin{array}{l}0.333^{* * *} \\
(0.051)\end{array}$ & $\begin{array}{c}0.083 \\
(0.148)\end{array}$ & $\begin{array}{c}0.120 \\
(0.111)\end{array}$ & $\begin{array}{l}0.259^{* * *} \\
(0.053)\end{array}$ & $\begin{array}{l}-0.140 \\
(0.113)\end{array}$ \\
\hline High & $\begin{array}{l}2.484 * * * \\
(0.733)\end{array}$ & $\begin{array}{l}1.234^{* * *} \\
(0.297)\end{array}$ & $\begin{array}{l}1.250^{*} \\
(0.717)\end{array}$ & $\begin{array}{l}1.296^{* *} \\
(0.650)\end{array}$ & $\begin{array}{l}-0.031 \\
(0.208)\end{array}$ & $\begin{array}{l}1.327^{* *} \\
(0.625)\end{array}$ \\
\hline Log DC Size & $\begin{array}{l}-0.163^{* * *} \\
(0.028)\end{array}$ & $\begin{array}{c}0.008 \\
(0.008)\end{array}$ & $\begin{array}{l}-0.171^{* * *} \\
(0.028)\end{array}$ & $\begin{array}{l}-0.114^{* * *} \\
(0.017)\end{array}$ & $\begin{array}{c}0.010 \\
(0.008)\end{array}$ & $\begin{array}{l}-0.123^{* * *} \\
(0.016)\end{array}$ \\
\hline Log Non-DC Size & $\begin{array}{c}0.046 \\
(0.029)\end{array}$ & $\begin{array}{l}-0.077^{* * *} \\
(0.013)\end{array}$ & $\begin{array}{l}0.122^{* * *} \\
(0.032)\end{array}$ & $\begin{array}{l}0.036^{* *} \\
(0.015)\end{array}$ & $\begin{array}{l}-0.066^{* * *} \\
(0.011)\end{array}$ & $\begin{array}{l}0.103^{* * *} \\
(0.017)\end{array}$ \\
\hline Log Family Size & $\begin{array}{c}0.039 * \\
(0.023)\end{array}$ & $\begin{array}{l}0.049 * * * \\
(0.010)\end{array}$ & $\begin{array}{l}-0.010 \\
(0.022)\end{array}$ & $\begin{array}{l}0.034^{* *} \\
(0.015)\end{array}$ & $\begin{array}{l}0.028^{* * *} \\
(0.008)\end{array}$ & $\begin{array}{c}0.006 \\
(0.014)\end{array}$ \\
\hline Log Age & $\begin{array}{c}0.015 \\
(0.034)\end{array}$ & $\begin{array}{l}-0.001 \\
(0.013)\end{array}$ & $\begin{array}{c}0.016 \\
(0.034)\end{array}$ & $\begin{array}{l}-0.078^{* *} \\
(0.032)\end{array}$ & $\begin{array}{c}0.012 \\
(0.015)\end{array}$ & $\begin{array}{l}-0.090^{* * *} \\
(0.031)\end{array}$ \\
\hline Expense Ratio & $\begin{array}{c}0.362 \\
(0.815)\end{array}$ & $\begin{array}{c}0.125 \\
(0.331)\end{array}$ & $\begin{array}{c}0.238 \\
(0.772)\end{array}$ & $\begin{array}{l}-0.435 \\
(0.673)\end{array}$ & $\begin{array}{l}-0.208 \\
(0.284)\end{array}$ & $\begin{array}{l}-0.227 \\
(0.619)\end{array}$ \\
\hline Turnover & $\begin{array}{c}0.000 \\
(0.027)\end{array}$ & $\begin{array}{l}-0.016^{*} \\
(0.009)\end{array}$ & $\begin{array}{c}0.017 \\
(0.024)\end{array}$ & $\begin{array}{l}-0.065^{* * *} \\
(0.023)\end{array}$ & $\begin{array}{l}-0.023^{*} \\
(0.013)\end{array}$ & $\begin{array}{l}-0.042 * \\
(0.025)\end{array}$ \\
\hline Volatility & $\begin{array}{c}1.423 \\
(1.104)\end{array}$ & $\begin{array}{c}0.540 \\
(0.354)\end{array}$ & $\begin{array}{c}0.883 \\
(1.110)\end{array}$ & $\begin{array}{l}-1.865 \\
(1.803)\end{array}$ & $\begin{array}{l}-1.845^{* *} \\
(0.726)\end{array}$ & $\begin{array}{l}-0.020 \\
(1.756)\end{array}$ \\
\hline Style Flow & $\begin{array}{l}-0.118 \\
(0.596)\end{array}$ & $\begin{array}{c}0.061 \\
(0.186)\end{array}$ & $\begin{array}{l}-0.179 \\
(0.612)\end{array}$ & $\begin{array}{c}0.400 \\
(0.375)\end{array}$ & $\begin{array}{l}0.417 * * \\
(0.171)\end{array}$ & $\begin{array}{l}-0.017 \\
(0.345)\end{array}$ \\
\hline Observations & 1,759 & 1,759 & 1,759 & 2,092 & 2,092 & 2,092 \\
\hline R-squared & 0.128 & 0.203 & 0.079 & 0.087 & 0.092 & 0.058 \\
\hline
\end{tabular}




\section{Table VI}

Piecewise Linear Panel Regressions of DC and Non-DC Flows with Size and Age Interaction Effects

This table summarizes the coefficients of a piecewise linear panel regression of DC and non-DC asset flows on fund variables. Low, Mid, and High represent the funds' ranked return performance where $\operatorname{Low}_{f, t}=\min \left(\operatorname{Rank}_{f, t}, 0.2\right), \operatorname{Mid}_{f, t}=\min \left(\operatorname{Rank}_{f, t}-\operatorname{Low}_{f, t}, 0.6\right)$, and $\operatorname{High}_{f, t}=$ $\left(\operatorname{Rank}_{f, t}-\operatorname{Low}_{f, t}-\operatorname{Mid}_{f, t}\right)$. The performance ranks are interacted with the logarithms of DC and non-DC sizes and with the logarithm of the age of the funds. All the continuous control variables are demeaned to facilitate the interpretation of the economic magnitude of the results. The other variables are characteristics of the fund. The standard errors of the coefficients are reported in parentheses and adjusted for clustering at the fund level. The regressions also include time-fixed effects. $*, * *$, and $* * *$ denote estimates that are statistically different from zero at the 10,5 , and 1 percent significance levels. 
Table VI (Cont.)

\begin{tabular}{|c|c|c|c|c|c|c|}
\hline & \multicolumn{3}{|c|}{ Size Interactions } & \multicolumn{3}{|c|}{ Age Interactions } \\
\hline & \multicolumn{3}{|c|}{ Non- } & \multicolumn{3}{|c|}{ Non- } \\
\hline & DC Flow & DC Flow & Difference & DC Flow & DC Flow & Difference \\
\hline \multirow[t]{2}{*}{ Low } & $0.970 * * *$ & $0.252 *$ & 0.718* & $1.147 * * *$ & $0.287 * *$ & $0.860 * *$ \\
\hline & $(0.370)$ & $(0.151)$ & $(0.372)$ & $(0.381)$ & $(0.141)$ & $(0.379)$ \\
\hline \multirow[t]{2}{*}{ Mid } & $0.258 * * *$ & $0.294 * * *$ & -0.036 & $0.252 * * *$ & $0.302 * * *$ & -0.050 \\
\hline & $(0.089)$ & $(0.038)$ & $(0.092)$ & $(0.092)$ & $(0.039)$ & $(0.095)$ \\
\hline \multirow[t]{2}{*}{ High } & $1.492 * * *$ & $0.365 * *$ & $1.128^{* * *}$ & $1.639 * * *$ & $0.373^{* *}$ & $1.266^{* * *}$ \\
\hline & $(0.418)$ & (0.159) & $(0.414)$ & $(0.489)$ & $(0.171)$ & $(0.476)$ \\
\hline Low * & -0.317 & $-0.154 *$ & -0.163 & & & \\
\hline Log DC Size & $(0.218)$ & $(0.091)$ & $(0.223)$ & & & \\
\hline Mid * & -0.065 & -0.002 & -0.063 & & & \\
\hline Log DC Size & $(0.083)$ & $(0.034)$ & $(0.081)$ & & & \\
\hline High * & -0.271 & 0.071 & -0.342 & & & \\
\hline Log DC Size & $(0.389)$ & $(0.138)$ & $(0.379)$ & & & \\
\hline Low * & 0.162 & 0.251 & -0.089 & & & \\
\hline Log Non-DC Size & (0.307) & $(0.165)$ & $(0.313)$ & & & \\
\hline Mid * & 0.033 & -0.034 & 0.067 & & & \\
\hline Log Non-DC Size & $(0.074)$ & $(0.047)$ & $(0.085)$ & & & \\
\hline High * & 0.149 & -0.311 & 0.460 & & & \\
\hline Log Non-DC Size & $(0.451)$ & $(0.221)$ & $(0.481)$ & & & \\
\hline Low * & & & & -0.023 & -0.034 & 0.011 \\
\hline Log Age & & & & $(0.445)$ & $(0.146)$ & $(0.458)$ \\
\hline Mid * & & & & -0.055 & $-0.078^{*}$ & 0.023 \\
\hline Log Age & & & & $(0.135)$ & $(0.046)$ & $(0.141)$ \\
\hline High * & & & & -0.702 & -0.446 & -0.256 \\
\hline Log Age & & & & $(0.686)$ & $(0.279)$ & $(0.641)$ \\
\hline \multirow[t]{2}{*}{ Log DC Size } & -0.052 & $0.035^{* *}$ & $-0.086 * * *$ & $-0.135 * * *$ & 0.008 & $-0.142^{* * *}$ \\
\hline & $(0.033)$ & $(0.014)$ & $(0.033)$ & $(0.017)$ & $(0.006)$ & $(0.016)$ \\
\hline \multirow[t]{2}{*}{ Log Non-DC Size } & -0.003 & $-0.101 * * *$ & $0.098^{*}$ & $0.040 * *$ & $-0.071 * * *$ & $0.111^{* * *}$ \\
\hline & $(0.054)$ & $(0.028)$ & $(0.054)$ & $(0.016)$ & $(0.009)$ & $(0.018)$ \\
\hline \multirow[t]{2}{*}{ Log Family Size } & $0.040 * * *$ & $0.039 * * *$ & 0.001 & $0.039 * * *$ & $0.039 * * *$ & 0.000 \\
\hline & $(0.014)$ & $(0.007)$ & $(0.013)$ & $(0.014)$ & $(0.007)$ & $(0.013)$ \\
\hline \multirow[t]{2}{*}{ Log Age } & -0.034 & 0.004 & $-0.038 *$ & -0.002 & $0.041^{*}$ & -0.044 \\
\hline & $(0.023)$ & $(0.010)$ & $(0.022)$ & $(0.068)$ & $(0.021)$ & $(0.069)$ \\
\hline \multirow[t]{2}{*}{ Expense Ratio } & -0.486 & -0.273 & -0.213 & -0.520 & -0.257 & -0.263 \\
\hline & $(0.540)$ & $(0.218)$ & $(0.500)$ & $(0.556)$ & $(0.217)$ & $(0.519)$ \\
\hline \multirow[t]{2}{*}{ Turnover } & -0.023 & $-0.019 * *$ & -0.004 & -0.026 & $-0.018^{* *}$ & -0.007 \\
\hline & $(0.018)$ & $(0.008)$ & $(0.016)$ & $(0.018)$ & $(0.008)$ & $(0.016)$ \\
\hline \multirow[t]{2}{*}{ Volatility } & 0.891 & 0.036 & 0.855 & 1.052 & 0.049 & 1.004 \\
\hline & $(0.854)$ & $(0.320)$ & $(0.842)$ & $(0.873)$ & $(0.317)$ & $(0.865)$ \\
\hline \multirow[t]{2}{*}{ Style Flow } & 0.391 & $0.307^{* *}$ & 0.084 & 0.351 & $0.281^{* *}$ & 0.070 \\
\hline & $(0.325)$ & $(0.132)$ & $(0.294)$ & $(0.324)$ & $(0.133)$ & $(0.296)$ \\
\hline Observations & 3,851 & 3,851 & 3,851 & 3,851 & 3,851 & 3,851 \\
\hline R-squared & 0.103 & 0.130 & 0.067 & 0.100 & 0.129 & 0.064 \\
\hline
\end{tabular}




\section{Table VII \\ Multinomial Logit for Entry and Exit Decisions}

This table summarizes the coefficient estimates of a multinomial logit specification for fund entry and exit decisions. The exit (entry) indicator variable equals one if funds have non-missing (missing) DC assets in the past year and missing (non-missing) DC assets in the current year. The base group consists of all funds in the sample that have non-missing DC assets for two consecutive years. The standard errors of the coefficients are reported in parentheses and adjusted for clustering at the fund level. The regressions also include time-fixed effects. *, **, and $* * *$ denote estimates that are statistically different from zero at the 10,5 , and 1 percent significance levels.

\begin{tabular}{lcc}
\hline & Exit & Entry \\
\hline Performance & $-0.958^{* * *}$ & $0.485^{* *}$ \\
& $(0.221)$ & $(0.203)$ \\
Log Fund Size & $-0.644^{* * *}$ & $-0.653^{* * *}$ \\
& $(0.060)$ & $(0.063)$ \\
Log Family Size & $0.594^{* * *}$ & $0.549^{* * *}$ \\
& $(0.058)$ & $(0.057)$ \\
Log Age & 0.071 & $-0.202^{* *}$ \\
& $(0.107)$ & $(0.099)$ \\
Expenses & $3.193^{*}$ & 0.953 \\
& $(1.828)$ & $(1.607)$ \\
Turnover & 0.065 & -0.020 \\
& $(0.058)$ & $(0.055)$ \\
Volatility & 2.368 & 1.184 \\
& $(2.734)$ & $(2.906)$ \\
Style Flow & $-3.161^{* *}$ & -1.050 \\
& $(1.289)$ & $(1.169)$ \\
Observations & & \\
\hline
\end{tabular}




\section{Table VIII}

Flow-Performance Panel Regressions for Plan Sponsors and Plan Participants

This table summarizes the coefficients of a piecewise linear panel regression of total plan as well as estimated plan sponsor and plan participant asset flows on fund variables based on 11-K filings of 401(k) plans. Low, Mid, and High represent the funds' ranked return performance over the prior year where $\operatorname{Low}_{f, t}=\min \left(\operatorname{Rank}_{f, t}, 0.2\right), \operatorname{Mid}_{f, t}=\min \left(\operatorname{Rank}_{f, t}-\operatorname{Low}_{f, t}, 0.6\right)$, and $\operatorname{High}_{f, t}=$ $\left(\operatorname{Rank}_{f, t}-\operatorname{Low}_{f, t}-\operatorname{Mid}_{f, t}\right)$. The other variables are characteristics of the fund. The standard errors of the coefficients are reported in parentheses and adjusted for clustering at the fund level. The regressions also include time-fixed effects.

\begin{tabular}{|c|c|c|c|c|c|c|}
\hline & \multicolumn{3}{|c|}{ Pensions and Investments Sample of Funds } & \multicolumn{3}{|c|}{ 11-K Sample of Funds } \\
\hline & $\begin{array}{c}\text { Total } \\
\text { Flows } \\
\end{array}$ & $\begin{array}{c}\text { Sponsor } \\
\text { Flows }\end{array}$ & $\begin{array}{c}\text { Participant } \\
\text { Flows } \\
\end{array}$ & $\begin{array}{c}\text { Total } \\
\text { Flows } \\
\end{array}$ & $\begin{array}{l}\text { Sponsor } \\
\text { Flows } \\
\end{array}$ & $\begin{array}{c}\text { Participant } \\
\text { Flows } \\
\end{array}$ \\
\hline Low & $\begin{array}{l}1.046^{* * *} \\
(0.399)\end{array}$ & $\begin{array}{l}1.050^{* * *} \\
(0.376)\end{array}$ & $\begin{array}{l}-0.004 \\
(0.111)\end{array}$ & $\begin{array}{l}0.773^{* * *} \\
(0.299)\end{array}$ & $\begin{array}{l}0.786 * * * \\
(0.274)\end{array}$ & $\begin{array}{l}-0.013 \\
(0.100)\end{array}$ \\
\hline Mid & $\begin{array}{l}0.465^{* * *} \\
(0.091)\end{array}$ & $\begin{array}{l}0.310^{* * * *} \\
(0.083)\end{array}$ & $\begin{array}{l}0.156^{* * *} \\
(0.024)\end{array}$ & $\begin{array}{l}0.516^{* * * *} \\
(0.068)\end{array}$ & $\begin{array}{l}0.380^{* * * *} \\
(0.062)\end{array}$ & $\begin{array}{l}0.135^{* * *} \\
(0.021)\end{array}$ \\
\hline High & $\begin{array}{l}1.584 * * * \\
(0.482)\end{array}$ & $\begin{array}{l}1.389 * * * \\
(0.427)\end{array}$ & $\begin{array}{c}0.194 \\
(0.136)\end{array}$ & $\begin{array}{l}0.744^{* *} \\
(0.324)\end{array}$ & $\begin{array}{l}0.718^{* *} \\
(0.291)\end{array}$ & $\begin{array}{c}0.026 \\
(0.101)\end{array}$ \\
\hline Log Plan Size & $\begin{array}{l}-0.089 * * * \\
(0.010)\end{array}$ & $\begin{array}{l}-0.063^{* * *} \\
(0.009)\end{array}$ & $\begin{array}{l}-0.026^{* * *} \\
(0.003)\end{array}$ & $\begin{array}{l}-0.092^{* * *} \\
(0.006)\end{array}$ & $\begin{array}{l}-0.065^{* * *} \\
(0.005)\end{array}$ & $\begin{array}{l}-0.027^{* * *} \\
(0.002)\end{array}$ \\
\hline Log Fund Size & $\begin{array}{c}0.047^{* *} \\
(0.021)\end{array}$ & $\begin{array}{c}0.036^{*} \\
(0.019)\end{array}$ & $\begin{array}{c}0.011^{*} \\
(0.006)\end{array}$ & $\begin{array}{l}0.048 * * * \\
(0.012)\end{array}$ & $\begin{array}{l}0.048^{* * *} \\
(0.011)\end{array}$ & $\begin{array}{l}-0.001 \\
(0.004)\end{array}$ \\
\hline Log Family Size & $\begin{array}{c}0.006 \\
(0.017)\end{array}$ & $\begin{array}{c}0.005 \\
(0.015)\end{array}$ & $\begin{array}{c}0.002 \\
(0.005)\end{array}$ & $\begin{array}{l}0.016^{* *} \\
(0.007)\end{array}$ & $\begin{array}{c}0.010^{*} \\
(0.006)\end{array}$ & $\begin{array}{l}0.006^{* *} \\
(0.003)\end{array}$ \\
\hline Log Age & $\begin{array}{l}-0.056^{*} \\
(0.033)\end{array}$ & $\begin{array}{l}-0.040 \\
(0.029)\end{array}$ & $\begin{array}{l}-0.016^{*} \\
(0.009)\end{array}$ & $\begin{array}{l}-0.076^{* * *} \\
(0.023)\end{array}$ & $\begin{array}{l}-0.053^{* * *} \\
(0.021)\end{array}$ & $\begin{array}{l}-0.023^{* * *} \\
(0.007)\end{array}$ \\
\hline Exp. Ratio & $\begin{array}{l}-1.473^{* * *} \\
(0.528)\end{array}$ & $\begin{array}{l}-1.136^{* *} \\
(0.478)\end{array}$ & $\begin{array}{l}-0.336^{* *} \\
(0.165)\end{array}$ & $\begin{array}{l}-0.741^{*} \\
(0.420)\end{array}$ & $\begin{array}{l}-0.531 \\
(0.353)\end{array}$ & $\begin{array}{l}-0.210 \\
(0.142)\end{array}$ \\
\hline Turnover & $\begin{array}{c}0.032 \\
(0.025)\end{array}$ & $\begin{array}{c}0.038 \\
(0.025)\end{array}$ & $\begin{array}{l}-0.006 \\
(0.007)\end{array}$ & $\begin{array}{l}-0.030^{*} \\
(0.018)\end{array}$ & $\begin{array}{l}-0.011 \\
(0.018)\end{array}$ & $\begin{array}{l}-0.020 * * * \\
(0.005)\end{array}$ \\
\hline Volatility & $\begin{array}{c}1.061 \\
(1.056)\end{array}$ & $\begin{array}{c}0.277 \\
(0.919)\end{array}$ & $\begin{array}{l}0.783^{* *} \\
(0.354)\end{array}$ & $\begin{array}{c}0.536 \\
(0.746)\end{array}$ & $\begin{array}{l}-0.037 \\
(0.647)\end{array}$ & $\begin{array}{l}0.573^{* *} \\
(0.254)\end{array}$ \\
\hline Style Flow & $\begin{array}{c}0.811^{* *} \\
(0.341)\end{array}$ & $\begin{array}{c}0.461 \\
(0.303)\end{array}$ & $\begin{array}{l}0.350^{* * *} \\
(0.087)\end{array}$ & $\begin{array}{l}0.873^{* * *} \\
(0.280)\end{array}$ & $\begin{array}{l}0.685^{* * *} \\
(0.254)\end{array}$ & $\begin{array}{c}0.188^{* *} \\
(0.082)\end{array}$ \\
\hline Observations & 2,815 & 2,815 & 2,815 & 8,268 & 8,268 & 8,268 \\
\hline R-squared & 0.120 & 0.081 & 0.115 & 0.083 & 0.054 & 0.079 \\
\hline
\end{tabular}




\section{Table IX}

\section{Return Predictability Regressions}

This table summarizes the coefficients of a regression of funds' long-term future performance on mutual fund flows from DC and nonDC investors and additional control variables. The table uses six different performance measures. The standard errors of the coefficients are reported in parentheses and adjusted for clustering at the fund level. The regressions also include time-fixed effects. *, $* *$, and $* * *$ denote estimates that are statistically different from zero at the 10, 5, and 1 percent significance levels. 
Table IX (Cont.)

\begin{tabular}{|c|c|c|c|c|c|c|}
\hline & Raw Performance & $\begin{array}{l}\text { Objective Code- } \\
\text { Adjusted } \\
\text { Performance }\end{array}$ & $\begin{array}{l}\text { Style-Adjusted } \\
\text { Performance }\end{array}$ & $\begin{array}{l}\text { CAPM-Adjusted } \\
\text { Performance }\end{array}$ & $\begin{array}{l}\text { Fama-French- } \\
\text { Adjusted } \\
\text { Performance }\end{array}$ & $\begin{array}{l}\text { Carhart- } \\
\text { Adjusted } \\
\text { Performance }\end{array}$ \\
\hline DC Flow & $\begin{array}{l}-0.262 \\
(0.163)\end{array}$ & $\begin{array}{l}-0.260 \\
(0.160)\end{array}$ & $\begin{array}{l}-0.091 \\
(0.133)\end{array}$ & $\begin{array}{l}-0.176 \\
(0.144)\end{array}$ & $\begin{array}{c}0.114 \\
(0.128)\end{array}$ & $\begin{array}{l}-0.011 \\
(0.121)\end{array}$ \\
\hline Non-DC Flow & $\begin{array}{l}-1.567 * * * \\
(0.455)\end{array}$ & $\begin{array}{l}-1.102 * * \\
(0.436)\end{array}$ & $\begin{array}{l}-0.815^{* *} \\
(0.351)\end{array}$ & $\begin{array}{l}-1.261 * * * \\
(0.405)\end{array}$ & $\begin{array}{l}-0.657 * * \\
(0.286)\end{array}$ & $\begin{array}{l}-0.948^{* * *} \\
(0.276)\end{array}$ \\
\hline Return over Past Year & $\begin{array}{l}0.089 * * * \\
(0.021)\end{array}$ & $\begin{array}{l}0.089 * * * \\
(0.022)\end{array}$ & $\begin{array}{c}0.021 \\
(0.023)\end{array}$ & $\begin{array}{l}0.132^{* * *} \\
(0.019)\end{array}$ & $\begin{array}{l}0.189 * * * \\
(0.019)\end{array}$ & $\begin{array}{l}0.162^{* * * *} \\
(0.018)\end{array}$ \\
\hline Log Size & $\begin{array}{l}-1.006^{* * *} \\
(0.183)\end{array}$ & $\begin{array}{l}-0.877 * * * \\
(0.179)\end{array}$ & $\begin{array}{l}-0.550^{* * *} \\
(0.145)\end{array}$ & $\begin{array}{l}-0.967 * * * \\
(0.169)\end{array}$ & $\begin{array}{l}-0.257^{* *} \\
(0.118)\end{array}$ & $\begin{array}{l}-0.352 * * * \\
(0.115)\end{array}$ \\
\hline Log Family Size & $\begin{array}{l}0.642^{* * *} \\
(0.168)\end{array}$ & $\begin{array}{l}0.553^{* * *} \\
(0.162)\end{array}$ & $\begin{array}{l}0.414 * * * \\
(0.134)\end{array}$ & $\begin{array}{l}0.598 * * * \\
(0.153)\end{array}$ & $\begin{array}{l}0.257^{* *} \\
(0.106)\end{array}$ & $\begin{array}{l}0.280^{* * *} \\
(0.103)\end{array}$ \\
\hline Log Age & $\begin{array}{l}-0.143 \\
(0.295)\end{array}$ & $\begin{array}{l}-0.038 \\
(0.292)\end{array}$ & $\begin{array}{c}0.109 \\
(0.228)\end{array}$ & $\begin{array}{l}-0.094 \\
(0.261)\end{array}$ & $\begin{array}{c}0.193 \\
(0.196)\end{array}$ & $\begin{array}{c}0.114 \\
(0.184)\end{array}$ \\
\hline Expense Ratio & $\begin{array}{c}0.089 \\
(0.408)\end{array}$ & $\begin{array}{l}-0.213 \\
(0.405)\end{array}$ & $\begin{array}{l}-0.969 * * * \\
(0.327)\end{array}$ & $\begin{array}{l}-0.352 \\
(0.388)\end{array}$ & $\begin{array}{l}-0.788^{* * *} \\
(0.253)\end{array}$ & $\begin{array}{l}-0.613^{* *} \\
(0.247)\end{array}$ \\
\hline Turnover & $\begin{array}{l}-0.444^{*} \\
(0.231)\end{array}$ & $\begin{array}{l}-0.604^{* * *} \\
(0.231)\end{array}$ & $\begin{array}{l}-0.615^{* * *} \\
(0.205)\end{array}$ & $\begin{array}{l}-0.379 * \\
(0.205)\end{array}$ & $\begin{array}{l}-0.568^{* * *} \\
(0.162)\end{array}$ & $\begin{array}{l}-0.531^{* * *} \\
(0.145)\end{array}$ \\
\hline DC Ratio & $\begin{array}{c}0.848 \\
(0.818)\end{array}$ & $\begin{array}{c}0.427 \\
(0.786)\end{array}$ & $\begin{array}{c}0.118 \\
(0.633)\end{array}$ & $\begin{array}{c}0.014 \\
(0.777)\end{array}$ & $\begin{array}{l}-0.275 \\
(0.516)\end{array}$ & $\begin{array}{l}-0.097 \\
(0.517)\end{array}$ \\
\hline Observations & 4,116 & 4,075 & 3,999 & 4,009 & 4,009 & 4,009 \\
\hline $\begin{array}{l}\text { R-squared } \\
p \text {-value for } F \text {-Test }\end{array}$ & 0.020 & 0.018 & 0.008 & 0.034 & 0.078 & 0.066 \\
\hline DC Flow=Non-DC Flow & $0.009 * * *$ & $0.074 *$ & $0.059 *$ & $0.016^{* *}$ & $0.024 * *$ & $0.004 * * *$ \\
\hline
\end{tabular}




\section{Appendix}

In this appendix we include some additional robustness tests not included in the main body of the paper. In addition, we explain in more detail the performance measures used in the paper.

\section{A. Robustness Tests}

Tables A-I through A-IV provide the results of additional robustness tests of the flowperformance sensitivity of DC and non-DC flows. In Table A-I we use two alternative functional forms for the performance rank:

$$
\begin{aligned}
& f_{\text {Linear }}\left(\operatorname{Rank}_{f, t}\right)=\gamma_{1}\left(\operatorname{Rank}_{f, t}-0.5\right) \\
& f_{\text {Cubic }}\left(\operatorname{Rank}_{f, t}\right)=\gamma_{1}\left(\operatorname{Rank}_{f, t}-0.5\right)+\gamma_{2}\left(\operatorname{Rank}_{f, t}-0.5\right)^{2}+\gamma_{3}\left(\operatorname{Rank}_{f, t}-0.5\right)^{3}
\end{aligned}
$$

In the linear specification we find that DC flows are more sensitive to performance than non-DC flows. For the cubic specification, only the cubic term is statistically significant for the DC flows and only the linear term is statistically significant for the non-DC flows, which is consistent with Figure 2.

In Table A-II we conduct cross-sectional regressions and then aggregate the coefficients across the years using the Fama-MacBeth (1973) approach. The primary variables of interest are low, middle, and high ranked return performance where the lowest is $\min \left(\operatorname{Rank}_{f, t}, 0.2\right)$, the middle is $\min \left(\operatorname{Rank}_{f, t}-\operatorname{Low}_{f, t}, 0.6\right)$, and the highest is $\left(\operatorname{Rank}_{f, t}-\operatorname{Low}_{f, t}-\operatorname{Mid}_{f, t}\right)$. We also control for other characteristics of the fund.

In Table A-III we show that the results of Table III are robust to different classifications of performance. We again use the panel regressions employed in the main body of the paper and 
run a piecewise linear panel regression of DC and non-DC asset flows on fund variables. Low, Mid, and High ranked return continue to represent the funds' ranked return performance but we change the definitions so that $\operatorname{Low}_{f, t}=\min \left(\operatorname{Rank}_{f, t}, 0.1\right.$ or 0.3$), \operatorname{Mid}_{f, t}=\min \left(\operatorname{Rank}_{f, t}-\operatorname{Low}_{f, t}\right.$, 0.8 or 0.4), and $\operatorname{High}_{f, t}=\left(\operatorname{Rank}_{f, t}-\operatorname{Low}_{f, t}-\operatorname{Mid}_{f, t}\right)$. The other variables are characteristics of the funds. The standard errors of the coefficients are reported in parentheses and adjusted for clustering at the fund level and the regressions also include time-fixed effects.

In Table A-IV we summarize the coefficients of a piecewise linear panel regression of DC and non-DC asset percentile flows on fund variables. The dependent variables are the percentiles of the DC and non-DC flows in each year and the percentile of the difference between the DC and non-DC flows. The other variables are characteristics of the fund. Consistent with our base case specification in Table III, we find that the percentile DC flows are more sensitive to top and bottom quintile performance than the middle three performance quintiles. Furthermore, the relation is close to linear using the percentile of non-DC flows.

\section{B. Details on Mutual Fund Performance Tests}

The performance measures we employ in the paper are the raw return, objective-adjusted return, style-adjusted return, CAPM-adjusted performance, Fama-French adjusted performance and Carhart adjusted performance. The objective-adjusted return is defined as the difference between the fund return and the mean return of funds in the same objective category. The styleadjusted return is defined as the difference between the fund return and the mean return of funds in the same style classification based on the fund holdings, where the holdings-based styles are determined by dividing mutual funds into terciles according to the mean size and the mean bookto-market ratio of their holdings. Thus, in each period we obtain 9 different fund styles according 
to the holdings (e.g., small-cap growth, mid-cap growth, large-cap growth, small-cap blend, ..., large-cap value).

Our performance measures also include several risk-adjusted measures of return including alphas from the Capital Asset Pricing Model, Fama-French (1993), model and Carhart (1997) model:

$$
\begin{aligned}
& R_{i, t}-R_{F, t}=\alpha_{i}+\beta_{i, M}\left(R_{M, t}-R_{F, t}\right)+\varepsilon_{i, t} \\
& R_{i, t}-R_{F, t}=\alpha_{i}+\beta_{i, M}\left(R_{M, t}-R_{F, t}\right)+\beta_{i, S M B} S M B_{t}+\beta_{i, H M L} H M L_{t}+\varepsilon_{i, t} \\
& R_{i, t}-R_{F, t}=\alpha_{i}+\beta_{i, M}\left(R_{M, t}-R_{F, t}\right)+\beta_{i, S M B} S M B_{t}+\beta_{i, H M L} H M L_{t}+\beta_{i, U M D} U M D_{t}+\varepsilon_{i, t}
\end{aligned}
$$

where $R_{i, t}-R_{F, t}$ and $R_{M, t}-R_{F, t}$ are the monthly excess returns on the fund portfolio and the market portfolio respectively, and $S M B_{t}, H M L_{t}$ and $U M D_{t}$ are the monthly size, value and momentum factor returns. ${ }^{31}$

${ }^{31}$ The market, size, book-to-market, momentum factors and the risk-free rate are obtained from Ken French's website (http://mba.tuck.dartmouth.edu/pages/faculty/ken.french/index.html). 


\section{Table A-I}

\section{Linear and Cubic Flow-Performance Relation}

This table summarizes the coefficients of linear and cubic panel regressions of DC and non-DC asset flows on fund variables. Rank captures the ranked performance and the other variables are characteristics of the fund. The standard errors of the coefficients are reported in parentheses and adjusted for clustering at the fund level. The regressions also include time-fixed effects. *, **, and $* * *$ denote estimates that are statistically different from zero at the 10,5 , and 1 percent significance levels.

\begin{tabular}{|c|c|c|c|c|c|c|}
\hline & \multicolumn{3}{|c|}{ Linear Specification } & \multicolumn{3}{|c|}{ Cubic Specification } \\
\hline & \multicolumn{3}{|c|}{ Non-DC } & \multicolumn{3}{|c|}{ Non-DC } \\
\hline & DC Flow & Flow & Difference & DC Flow & Flow & Difference \\
\hline \multirow[t]{2}{*}{ (Rank-0.5) } & $0.494 * * *$ & $0.311 * * *$ & $0.183^{* * *}$ & 0.131 & $0.260 * * *$ & -0.129 \\
\hline & $(0.059)$ & $(0.023)$ & $(0.058)$ & $(0.126)$ & $(0.053)$ & $(0.129)$ \\
\hline \multirow[t]{2}{*}{$(\text { Rank-0.5) })^{2}$} & & & & 0.064 & 0.057 & 0.007 \\
\hline & & & & $(0.243)$ & $(0.084)$ & $(0.235)$ \\
\hline \multirow[t]{2}{*}{$(\text { Rank-0.5) })^{3}$} & & & & $2.454^{* * *}$ & 0.335 & $2.118^{* *}$ \\
\hline & & & & $(0.855)$ & $(0.331)$ & $(0.849)$ \\
\hline \multirow[t]{2}{*}{ Log DC Size } & $-0.137 * * *$ & 0.007 & $-0.144 * * *$ & $-0.136 * * *$ & 0.007 & $-0.143^{* * *}$ \\
\hline & $(0.017)$ & $(0.006)$ & $(0.016)$ & $(0.017)$ & $(0.006)$ & $(0.016)$ \\
\hline \multirow[t]{2}{*}{ Log Non-DC Size } & $0.041^{* *}$ & $-0.070 * * *$ & $0.111^{* * *}$ & $0.041^{* *}$ & $-0.070 * * *$ & $0.111^{* * *}$ \\
\hline & $(0.017)$ & $(0.009)$ & $(0.018)$ & $(0.016)$ & $(0.009)$ & $(0.018)$ \\
\hline \multirow[t]{2}{*}{ Log Family Size } & $0.040 * * *$ & $0.039 * * *$ & 0.001 & $0.040 * * *$ & $0.039 * * *$ & 0.001 \\
\hline & $(0.014)$ & $(0.007)$ & $(0.013)$ & $(0.014)$ & $(0.007)$ & $(0.013)$ \\
\hline \multirow[t]{2}{*}{ Log Age } & $-0.041^{*}$ & 0.002 & $-0.043^{*}$ & -0.038 & 0.003 & $-0.041^{*}$ \\
\hline & $(0.024)$ & $(0.010)$ & $(0.022)$ & $(0.024)$ & $(0.010)$ & $(0.022)$ \\
\hline \multirow[t]{2}{*}{ Expense Ratio } & -0.387 & -0.202 & -0.185 & -0.411 & -0.222 & -0.189 \\
\hline & $(0.543)$ & $(0.216)$ & $(0.499)$ & $(0.556)$ & $(0.220)$ & $(0.515)$ \\
\hline \multirow[t]{2}{*}{ Turnover } & -0.026 & $-0.018^{* *}$ & -0.008 & -0.026 & $-0.018 * *$ & -0.008 \\
\hline & (0.019) & $(0.008)$ & $(0.016)$ & $(0.019)$ & $(0.008)$ & $(0.016)$ \\
\hline \multirow[t]{2}{*}{ Volatility } & 1.067 & 0.052 & 1.015 & 1.174 & 0.023 & 1.151 \\
\hline & (0.815) & $(0.314)$ & $(0.813)$ & $(0.871)$ & $(0.317)$ & (0.863) \\
\hline \multirow[t]{2}{*}{ Style Flow } & 0.362 & $0.283^{* *}$ & 0.079 & 0.362 & $0.282 * *$ & 0.080 \\
\hline & $(0.326)$ & $(0.132)$ & $(0.297)$ & $(0.324)$ & $(0.132)$ & $(0.295)$ \\
\hline Observations & 3,851 & 3,851 & 3,851 & 3,851 & 3,851 & 3,851 \\
\hline R-squared & 0.095 & 0.124 & 0.061 & 0.097 & 0.124 & 0.063 \\
\hline
\end{tabular}




\section{Table A-II}

Fama-MacBeth Regressions of DC and non-DC Asset Flows

This table summarizes the coefficients of piecewise linear regressions of DC and non-DC asset flows on fund variables, where we aggregate across years using the Fama-MacBeth (1973) approach. Low, Mid, and High represent the funds' ranked return performance where Low $_{f, t}=$ $\min \left(\operatorname{Rank}_{f, t}, 0.2\right), \operatorname{Mid}_{f, t}=\min \left(\operatorname{Rank}_{f, t}-\operatorname{Low}_{f, t}, 0.6\right)$, and $\operatorname{High}_{f, t}=\left(\operatorname{Rank}_{f, t}-\operatorname{Low}_{f, t}-M_{i d_{f, t}}\right)$. The other variables are characteristics of the fund. The standard errors of the coefficients are reported in parentheses. ${ }^{*}, * *$, and $* * *$ denote estimates that are statistically different from zero at the 10 , 5 , and 1 percent significance levels.

\begin{tabular}{lccc}
\hline & DC Flow & Non-DC Flow & Difference \\
\hline Low & $1.261^{* * *}$ & $0.380^{* *}$ & $0.881^{* *}$ \\
Mid & $(0.308)$ & $(0.157)$ & $0.310)$ \\
& $0.345^{* * *}$ & $0.329^{* * *}$ & 0.016 \\
High & $(0.093)$ & $(0.063)$ & $(0.080)$ \\
& $1.768^{* * *}$ & $0.738^{* *}$ & $1.030^{* *}$ \\
Log DC Size & $(0.416)$ & $(0.246)$ & $(0.360)$ \\
& $-0.140^{* * *}$ & 0.006 & $-0.146^{* * *}$ \\
Log Non-DC Size & $(0.021)$ & $(0.007)$ & $(0.022)$ \\
& $0.049^{* * *}$ & $-0.068^{* * *}$ & $0.117^{* * *}$ \\
Log Family Size & $(0.012)$ & $(0.011)$ & $(0.017)$ \\
& 0.026 & $0.037^{* * *}$ & -0.011 \\
Log Age & $(0.019)$ & $(0.008)$ & $(0.016)$ \\
& -0.033 & 0.001 & -0.034 \\
Expense Ratio & $(0.035)$ & $(0.012)$ & $(0.034)$ \\
& -0.248 & 0.030 & -0.278 \\
Turnover & $(0.371)$ & $(0.201)$ & $(0.477)$ \\
& -0.026 & -0.019 & -0.007 \\
Volatility & $(0.031)$ & $(0.017)$ & $(0.027)$ \\
& -0.007 & -1.479 & 1.473 \\
Style Flow & $(3.051)$ & $(0.965)$ & $(3.062)$ \\
& -0.189 & 0.183 & -0.372 \\
Number of Dates & $(0.563)$ & $(0.162)$ & $(0.578)$ \\
\hline
\end{tabular}




\section{Table A-III}

Piecewise Linear Panel Regression with Different Cut-Off Levels for Performance

This table summarizes the coefficients of a piecewise linear panel regression of DC and non-DC asset flows on fund variables. Low, Mid, and High represent the funds' ranked return performance where $\operatorname{Low}_{f, t}=\min \left(\operatorname{Rank}_{f, t}, 0.1\right.$ or 0.3$), \operatorname{Mid}_{f, t}=\min \left(\operatorname{Rank}_{f, t}-\operatorname{Low}_{f, t}, 0.8\right.$ or 0.4$)$, and $\operatorname{High}_{f, t}=\left(\operatorname{Rank}_{f, t}-\operatorname{Low}_{f, t}-\operatorname{Mid}_{f, t}\right)$. The other variables are characteristics of the fund. The standard errors of the coefficients are reported in parentheses and adjusted for clustering at the fund level. The regressions also include time-fixed effects. *, **, and $* * *$ denote estimates that are statistically different from zero at the 10,5 , and 1 percent significance levels.

\begin{tabular}{|c|c|c|c|c|c|c|}
\hline & \multicolumn{3}{|c|}{ 10/80/10 Classification } & \multicolumn{3}{|c|}{ 30/40/30 Classification } \\
\hline & \multicolumn{3}{|c|}{ Non-DC } & \multicolumn{3}{|c|}{ Non-DC } \\
\hline & DC Flow & Flow & Difference & DC Flow & Flow & Difference \\
\hline \multirow[t]{2}{*}{ Low } & $2.104^{* *}$ & 0.134 & $1.970 * *$ & $0.781 * * *$ & $0.404 * * *$ & $0.377^{*}$ \\
\hline & $(0.939)$ & $(0.351)$ & $(0.881)$ & $(0.223)$ & $(0.085)$ & $(0.228)$ \\
\hline \multirow[t]{2}{*}{ Mid } & $0.382^{* * *}$ & $0.317 * * *$ & 0.065 & 0.182 & $0.212 * * *$ & -0.031 \\
\hline & $(0.066)$ & $(0.028)$ & $(0.067)$ & $(0.128)$ & $(0.055)$ & $(0.135)$ \\
\hline \multirow[t]{2}{*}{ High } & $2.781^{* *}$ & 0.260 & $2.522^{* *}$ & $1.032 * * *$ & $0.479 * * *$ & $0.553^{*}$ \\
\hline & $(1.238)$ & $(0.470)$ & $(1.181)$ & $(0.296)$ & $(0.105)$ & $(0.285)$ \\
\hline \multirow[t]{2}{*}{ Log DC Size } & $-0.136 * * *$ & 0.007 & $-0.143^{* * *}$ & $-0.136 * * *$ & 0.007 & $-0.143^{* * *}$ \\
\hline & $(0.017)$ & $(0.006)$ & $(0.016)$ & $(0.017)$ & $(0.006)$ & $(0.016)$ \\
\hline \multirow[t]{2}{*}{ Log Non-DC Size } & $0.040 * *$ & $-0.070 * * *$ & $0.111^{* * *}$ & $0.041^{* *}$ & $-0.070 * * *$ & $0.111^{* * *}$ \\
\hline & $(0.017)$ & $(0.009)$ & $(0.018)$ & $(0.016)$ & $(0.009)$ & $(0.018)$ \\
\hline \multirow[t]{2}{*}{ Log Family Size } & $0.039 * * *$ & $0.039 * * *$ & 0.000 & $0.040^{* * *}$ & $0.039 * * *$ & 0.001 \\
\hline & $(0.014)$ & $(0.007)$ & $(0.013)$ & $(0.014)$ & $(0.007)$ & $(0.013)$ \\
\hline \multirow[t]{2}{*}{ Log Age } & -0.039 & 0.002 & $-0.041 *$ & -0.038 & 0.003 & $-0.041^{*}$ \\
\hline & $(0.024)$ & $(0.010)$ & $(0.022)$ & $(0.024)$ & $(0.010)$ & $(0.022)$ \\
\hline \multirow[t]{2}{*}{ Expense Ratio } & -0.440 & -0.206 & -0.235 & -0.427 & -0.214 & -0.213 \\
\hline & (0.546) & $(0.217)$ & $(0.505)$ & $(0.557)$ & $(0.220)$ & $(0.516)$ \\
\hline \multirow[t]{2}{*}{ Turnover } & -0.026 & $-0.018^{* *}$ & -0.008 & -0.027 & $-0.018^{* *}$ & -0.008 \\
\hline & (0.019) & $(0.008)$ & $(0.016)$ & $(0.019)$ & $(0.008)$ & $(0.016)$ \\
\hline \multirow[t]{2}{*}{ Volatility } & 1.103 & 0.025 & 1.078 & 1.029 & 0.042 & 0.987 \\
\hline & $(0.864)$ & $(0.321)$ & $(0.852)$ & $(0.862)$ & $(0.315)$ & $(0.853)$ \\
\hline \multirow[t]{2}{*}{ Style Flow } & 0.355 & $0.283^{* *}$ & 0.072 & 0.364 & $0.283^{* *}$ & 0.081 \\
\hline & (0.325) & $(0.132)$ & $(0.296)$ & $(0.324)$ & $(0.132)$ & $(0.296)$ \\
\hline Observations & 3,851 & 3,851 & 3,851 & 3,851 & 3,851 & 3,851 \\
\hline R-squared & 0.097 & 0.124 & 0.063 & 0.097 & 0.125 & 0.062 \\
\hline
\end{tabular}




\section{Table A-IV}

Piecewise Linear Panel Regressions of DC and Non-DC Flows Using Percentile Flows

This table summarizes the coefficients of a piecewise linear panel regression of DC and non-DC asset percentile flows on fund variables. The dependent variables are the percentiles of the DC and non-DC flows in each year and the percentile of the difference between the DC and non-DC flows. Low, Mid, and High represent the funds' ranked return performance where $\operatorname{Low}_{f, t}=$ $\min \left(\operatorname{Rank}_{f, t}, 0.2\right), \operatorname{Mid}_{f, t}=\min \left(\operatorname{Rank}_{f, t}-\operatorname{Low}_{f, t}, 0.6\right)$, and $\operatorname{High}_{f, t}=\left(\operatorname{Rank}_{f, t}-\operatorname{Low}_{f, t}-\operatorname{Mid}_{f, t}\right)$. The other variables are characteristics of the fund. The standard errors of the coefficients are reported in parentheses and adjusted for clustering at the fund level. The regressions also include timefixed effects. *, **, and $* * *$ denote estimates that are statistically different from zero at the 10,5 , and 1 percent significance levels.

\begin{tabular}{lccc}
\hline & $\begin{array}{c}\text { Percentile of } \\
\text { DC Flows }\end{array}$ & $\begin{array}{c}\text { Percentile of } \\
\text { Non-DC Flow }\end{array}$ & $\begin{array}{c}\text { Percentile of } \\
\text { Difference Between } \\
\text { DC and Non-DC Flows }\end{array}$ \\
\hline Low & $0.508^{* * *}$ & $0.318^{* * *}$ & $0.305^{* * *}$ \\
Mid & $(0.122)$ & $(0.115)$ & $(0.116)$ \\
High & $0.168^{* * *}$ & $0.339^{* * *}$ & -0.018 \\
& $(0.028)$ & $(0.028)$ & $(0.028)$ \\
Log DC Size & $0.423^{* * *}$ & $0.189^{*}$ & $0.351^{* * *}$ \\
& $(0.126)$ & $(0.113)$ & $(0.124)$ \\
Log Non-DC Size & $-0.027^{* * *}$ & -0.002 & $-0.026^{* * *}$ \\
& $(0.004)$ & $(0.004)$ & $(0.004)$ \\
Log Family Size & $0.011^{* *}$ & $-0.027^{* * *}$ & $0.029^{* * *}$ \\
Log Age & $(0.005)$ & $(0.005)$ & $(0.005)$ \\
Expense Ratio & $0.021^{* * *}$ & $0.026^{* * *}$ & 0.003 \\
Turnover & $(0.004)$ & $(0.005)$ & $(0.004)$ \\
& $-0.031^{* * *}$ & -0.005 & $-0.025^{* * *}$ \\
Volatility & $(0.007)$ & $(0.008)$ & $(0.007)$ \\
& $-0.356^{* *}$ & $-0.655^{* * *}$ & 0.103 \\
Style Flow & $(0.152)$ & $(0.168)$ & $(0.140)$ \\
& $-0.009^{*}$ & $-0.028^{* * *}$ & $0.010^{* *}$ \\
Observations & $(0.005)$ & $(0.005)$ & $(0.005)$ \\
R-squared & $0.798^{* * *}$ & -0.069 & $0.694^{* * *}$ \\
& $(0.304)$ & $(0.249)$ & $(0.259)$ \\
& $0.255^{* * *}$ & $0.266^{* * *}$ & 0.070 \\
& $(0.093)$ & $(0.097)$ & $(0.082)$ \\
& 3,851 & 3,851 & 3,851 \\
& 0.097 & 0.152 & 0.040 \\
\hline
\end{tabular}

